Trinity University

Digital Commons @ Trinity

Geosciences Faculty Research

Geosciences Department

2005

\title{
Chromian Spinel-Olivine Phase Chemistry and the Origin of Primitive Basalts of the Southern Washington Cascades
}

Diane R. Smith

Trinity University, dsmith@trinity.edu

W. P. Leeman

Follow this and additional works at: https://digitalcommons.trinity.edu/geo_faculty

Part of the Earth Sciences Commons

\section{Repository Citation}

Smith, D.R., \& Leeman, W.P. (2004) Chromian spinel-olivine phase chemistry and the origin of primitive basalts of the southern

Washington cascades. Journal of Volcanology and Geothermal Research, 140(1-3), 49-66. doi:10.1016/j.jvolgeores.2004.07.015

This Post-Print is brought to you for free and open access by the Geosciences Department at Digital Commons @ Trinity. It has been accepted for inclusion in Geosciences Faculty Research by an authorized administrator of Digital Commons @ Trinity. For more information, please contact jcostanz@trinity.edu. 


\title{
Chromian spinel-olivine phase chemistry and the origin of primitive basalts of the southern
} Washington Cascades

\author{
D.R. Smith ${ }^{\mathrm{a}} *$, W.P. Leeman ${ }^{\mathrm{b}}$
}

${ }^{a}$ Department of Geosciences, Trinity University, One Trinity Place, San Antonio, TX 78212-7200, USA

${ }^{\mathrm{b}}$ Department of Earth Sciences, MS 126, Rice University, Houston, TX 77251-1892, USA

\begin{abstract}
Geochemically diverse basalts occur in an $\sim 160-\mathrm{km}$-wide transect that stretches across the Quaternary southern Washington Cascades (SWC) volcanic arc. Two fundamental groups of SWC basalts can be identified on the basis of major and trace element chemistry. On primitive mantle-normalized "spidergrams", Group I lavas resemble within-plate basalts, whereas Group II lavas exhibit chemical characteristics (e.g., $\mathrm{Nb}$, Ta, and Ti depletions) typical of subduction-related magmas. The primitive nature of many SWC basalts is indicated by their high $\mathrm{MgO}$ (>6.5 wt.\%, up to $9.5 \mathrm{wt} . \%$ ), $\mathrm{Ni}$ (>85 ppm) and $\mathrm{Cr}(>180 \mathrm{ppm})$ contents. Electron microprobe analyses of olivine-spinel pairs in a diverse suite of SWC basalts are used to further evaluate the primitive nature of these magmas. Some of the observed variations in olivine-spinel compositions can be attributed to oxidation, fractionation, mixing, and/or pressure variations during magma evolution. To minimize these effects, we focus on olivine-hosted spinels in samples for which olivine-host rock equilibrium can be demonstrated. Spinels in such rocks have $\mathrm{Fe}_{2} \mathrm{O}_{3}<16.5$ wt. $\%, 100 \mathrm{Fe}^{3+} /\left(\mathrm{Fe}^{3+}+\mathrm{Cr}+\mathrm{Al}\right)<22$, and exhibit high $\mathrm{Mg} \#\left[=100 \mathrm{Mg} /\left(\mathrm{Mg}+\mathrm{Fe}^{2+}\right)>44\right]$ and low $\mathrm{Cr} \#[=100 \mathrm{Cr} /(\mathrm{Cr}+\mathrm{Al})<58]$. For the most primitive spinel-olivine pairs: (1) spinel $\mathrm{Cr} \#$ ranges from 20 to 57; (2) spinel Cr\# for Group I lavas are distinctly lower $(<41)$ than those (> 45) for Group II lavas; (3) spinel Mg\# ranges from 45 to 71, and overlaps for Groups I and II. However, each group defines distinct trends on $\mathrm{Mg \#}$ vs. Cr\# and other variation diagrams, with Group II having more refractory characteristics. This observation is consistent with higher whole-rock Mg\# and Fo contents of olivines for Group II lavas, and suggests that sources for those magmas are more refractory (i.e., more meltdepleted) than sources for Group I lavas. The "within-plate"-like chemistry of Group I lavas precludes significant slab-derived contributions and is consistent with their derivation by decompression melting of little modified and relatively fertile mantle wedge material upwelling beneath the arc. The fluid-mobile element-enriched nature of Group II lavas is consistent with melting of a mantle source(s) that has been modified by slab-derived fluids. However, the standard "flux melting" process invoked to explain formation of many arc magmas is problematic for the Cascades because (a) high temperatures inferred for
\end{abstract}


the Cascadia subduction zone imply that the slab may be extensively dehydrated, in which case the inventory of volatiles and fluid-mobile elements is likely to be strongly depleted; and (b) Group I lavas occur at the volcanic front and appear to originate at depths proximal to the subducting slab. These geochemical and geometric constraints seem inconsistent with formation of Group II magmas by flux melting of the mantle wedge as commonly proposed for arcs. An alternative source for Group II lavas is chemically refractory lithospheric mantle that was previously metasomatized by earlier (40 Ma to present) Cascadia subduction and associated magmatism. Reheating and melting of such fluid-enriched domains could result from influx of hot decompression melts (Group I magmas). In either case, chemical and mineralogical evidence implicates two (or more) distinct processes of melt production and at least two distinct types of mantle source.

Keywords: subduction; basalt; chromian spinel; olivine; petrogenesis; Cascades

\section{Introduction}

The chemistry of chromian spinel inclusions and coexisting host olivine phenocrysts has been used in interpreting the partial melting and crystallization history of basaltic magmas from a variety of tectonic settings (Roeder, 1994; Arai, 1994; Clynne and Borg, 1997; Kamenetsky et al., 2001). Chromian spinels occurring as inclusions in olivine phenocrysts from mafic magmas show a wide range of compositions (e.g., Allan et al., 1988) resulting from many factors, including crystallization temperature (e.g., Thy, 1995), pressure (e.g., Sigurdsson and Schilling, 1976; Roeder and Reynolds, 1991), oxygen fugacity (e.g., Roeder and Reynolds, 1991; Ballhaus et al., 1991), melt differentiation (e.g., Arai, 1994; Clynne and Borg, 1997) and/or magma mixing/mingling (e.g., Thy, 1983; Natland et al., 1983). However, when carefully screened to minimize these effects, compositions of spinel inclusions and host olivine phenocrysts have proved to be useful indicators of the most primitive aspects of melt composition (Clynne and Borg, 1997), and thus the nature of partial melting processes and mantle sources (Dick and Bullen, 1984; Dick, 1989; Fujii, 1989).

We present here new microprobe analyses of chromian spinels and contiguous host olivines occurring in primitive basalts from a SWC transect across the southern Washington Cascades (SWC) volcanic arc (Fig. 1). Our goals are: (1) to utilize these data, in combination with whole-rock major and trace element geochemistry, to constrain the nature of the mantle source(s) for these magmas; (2) to determine if mineral compositions are consistent with phase equilibria; and (3) to evaluate existing petrologic models for the origin of Cascades basaltic magmas in the context of our results. 


\section{Tectonic and geological setting}

Cascadia subduction in the Pacific Northwest dates back to 35-40 Ma (cf. Sherrod and Smith, 2000), and comprises older (40-10 Ma) Western Cascades and younger $(<10 \mathrm{Ma})$ High Cascades age groups (Verplanck and Duncan, 1987). Quaternary (<2 Ma) High Cascades volcanism extends from southern British Columbia to northern California (Fig. 1) and is the result of slow ( $<4 \mathrm{~cm} / y e a r)$ subduction of the young (<10 Ma) Juan de Fuca and Gorda oceanic plates beneath North America (Riddihough, 1984; Wang et al., 2003). Due to its young age, the subducted slab is relatively warm, as confirmed by geophysical and petrologic thermal models (e.g., Hyndman and Wang, 1993; Peacock and Leeman, 1994; Green and Harry, 1999; Currie et al., 2003; Leeman et al., 2004). The dip of the subducting Juan de Fuca plate varies along the arc $\left(\sim 25-40^{\circ}\right.$; Romanyuk et al., 1998) but is defined by Benioff zone seismicity only to depths of about $100 \mathrm{~km}$ (Weaver and Michaelson, 1985; Michaelson and Weaver, 1986; Fig. 1), presumably because the slab is unusually warm. In southern Washington, the sub-arc crust is about 35-40 km thick (Mooney and Weaver, 1989; Chulick et al., 2001) and is composed of Tertiary arc igneous rocks (Bacon et al., 1997). Near the SWC transect, owing to oblique convergence (Wells et al., 1999), the greatest principal stress is north-south compression and the least principal stress corresponds to east-west extension (Zoback and Zoback, 1980; McCrory, 1996; Wang et al., 2003). Many volcanic vents in the Oregon and northern California High Cascades are localized along NNW oriented trends or structures (e.g., grabens and normal faults); this observation and an abundance of basaltic lavas suggest an important component of intra-arc extension (Conrey and Sherrod, 2003).

In southern Washington, the High Cascades arc forms a $\sim 160-\mathrm{km}$-wide belt, which includes two major composite volcanoes (Mount St. Helens and Mount Adams) and numerous smaller lava fields, shields, and cinder cones (Hammond and Korosec, 1983; Leeman et al., 1990; Bacon et al., 1997). Geological mapping and dating show that Quaternary ( $<1 \mathrm{Ma})$ mafic volcanism occurs in the frontal arc as much as $30 \mathrm{~km}$ west of Mount St. Helens (Fleck et al., 2002). Mount St. Helens has been active for at least $\sim 40,000$ years (Mullineaux, 1996) and nearby volcanism extends back to 300,000 years (Evarts et al., 2003). Magmas erupted from Mount St. Helens range in composition from basalt to dacite, but basaltic lavas apparently extruded only during the Castle Creek eruptive period (1500-2500 years B.P.; Hoblitt et al., 1980; Mullineaux, 1996). The Indian Heaven volcanic field, located between and a little south of Mount St. Helens and Mount Adams, is dominated by basaltic lavas with minor andesite (Hammond and Korosec, 1983; Swanson et al., 1989; Leeman et al., 1990). All eruptive units are younger than the last magnetic reversal $(0.78 \mathrm{Ma}$ ), and at least one (Big Lava Bed) is $<10,000$ years B.P. Mount Adams, one of the largest Cascade volcanoes, is located about $50 \mathrm{~km}$ due east of Mount St. Helens. Most of the main 
cone is younger than 220,000 years B.P. and comprises lava flows and pyroclastic materials of andesitic to dacitic composition (Hoblitt et al., 1987; Hildreth and Fierstein, 1997); flank vents produced basaltic and andesitic lavas as recently as 3500 B.P. (Hoblitt et al., 1987). Farthest from the trench, the Pliocene ( $<2$ to $4 \mathrm{Ma}$ ) Simcoe lava field produced basaltic lavas from dispersed monogenetic vents (cf. Leeman et al., 1990).

\section{Sampling and methods}

For this study, we consider only Quaternary (<ca. $1 \mathrm{Ma}$ ) basalt and basaltic andesite samples that are compositionally primitive (see below). These samples span all but the easternmost part of the transect (i.e., they exclude the Simcoe field), and represent all known compositional variants (cf. Leeman et al., 2004). The samples studied are only moderately porphyritic $(<5-10 \%$ phenocrysts; most $<5 \%)$ with olivine as the dominant phase; many lack phenocrystic plagioclase and appear to have ascended directly from mantle depths. The olivine phenocrysts typically contain subrounded to euhedral spinel inclusions ( 20 up to $100 \mu \mathrm{m}$ in diameter). Some Group II frontal arc basalts contain clinopyroxene phenocrysts, but these are generally subordinate to olivine in volume and size. Trace or microphenocrystic clinopyroxene occurs in other Group II basaltic lavas, but has not been observed in most Group I basalts. As notable exceptions, basalts from Mount St. Helens are relatively evolved and contain conspicuous plagioclase phenocrysts; they are included in this study for comparative purposes as they represent the most primitive lavas available from this volcano.

Electron microprobe methods were used to analyze olivine phenocrysts and coexisting spinel inclusions in 28 selected samples of SWC lavas, including: eleven from Indian Heaven, seven from the frontal arc, five from Mount St. Helens, and five from vents peripheral to Mount Adams (Tables 1 and 2). Microprobe analyses were obtained on polished thin sections of the host rocks or, in some cases, grain mounts of separated olivines, using natural and synthetic minerals as standards. In all cases, accelerating voltage of $15 \mathrm{kV}$ and specimen beam current of $30 \mathrm{nA}$ were used. Because we used instruments at several institutions (Rensselaer Polytechnic Institute, University of Texas at Austin, University of Tasmania), replicate analyses were made for selected samples in at least two laboratories to evaluate analytical reproducibility; in all cases, olivine and spinel data agree within expected analytical uncertainties (e.g., better than $0.5 \mathrm{~mol} \%$ forsterite in olivine). Proportions of $\mathrm{Fe}^{3+}$ and end member components in spinel were calculated assuming stoichiometry via the method of Stormer (1983).

Whole-rock analyses of the selected samples were determined using a combination of X-ray fluorescence, 
instrumental neutron activation, and inductively coupled plasma spectrometric methods, as described in Smith and Leeman (1987), Leeman et al. (1990), and Smith and Leeman (1993). Replicate analyses of standards indicate typical accuracy and precision for major (1-5\%) and trace elements (2-10\%).

\section{Geochemistry of SWC basalts}

Major and trace element compositions for SWC basalts studied here are given in Table 1 and a more extensive compilation of analyses is presented by Leeman et al. (2005). Major elements are normalized to $100 \%$ on an anhydrous basis and all iron is reported as $\mathrm{FeO}^{*}$. Selected geochemical characteristics of SWC basalts are illustrated in Fig. 2 and incompatible trace element compositions, normalized to primitive mantle (Sun and McDonough, 1989), are shown in Fig. 3.

Two fundamental groups of SWC basalts can be identified on the basis of major and trace element chemistry (Lewis et al., 2001; Leeman et al., 2004). Group I includes lavas with trace element geochemistry similar to so-called intraplate (e.g., OIB) basalts, whereas Group II includes lavas with compositional similarities to more typical calcalkalic volcanic arc basalts. Based on $\mathrm{K}_{2} \mathrm{O}$ and incompatible trace element abundances (cf. Figs. 2 and 3), Groups I and II can each be subdivided into three sub-types (cf. Leeman et al., 2004). Group I includes: (1) low-potassium tholeiites (LKT); (2) hynormative basalts with trace element patterns similar to ocean island basalts (OIB); and (3) basalts that are geochemically similar to OIB, but are ne-normative (ALK). Group II includes: (1) calcalkaline basalts (CA); (2) basaltic andesites (BA); and (3) shoshonites (SHOS). As discussed elsewhere (Leeman et al., 1990, 2004; Lewis et al., 2001), the observed diversity of SWC basalts must reflect variability in mantle sources, differences in melting processes or both. The little-evolved nature of many SWC basalts studied here is indicated by their high abundances of $\mathrm{MgO}$ (up to $9.5 \mathrm{wt} \%$ ), $\mathrm{Ni}$, and $\mathrm{Cr}$ (cf. Table 1). As noted in Section 3, basalts from Mount St. Helens are the least primitive of the samples considered here (e.g., wt. $\% \mathrm{MgO}=\sim 5.9$ to 6.8 ; cf. Table 1). Based on extensive chemical analyses, these lavas are interpreted as the products of "cryptic" magma mixing, involving at least two distinct mafic magma end members (Leeman et al., manuscript in preparation). Diverse and/or primitive basalts similar to those in the SWC have been found elsewhere in the Canadian (Green and Harry, 1999), central Washington (Reiners et al., 2000), Oregon (Bacon et al., 1997; Conrey et al., 1997), and especially in the northern California (Borg et al., 1997; Elkins-Tanton et al., 2001) High Cascades. 


\section{Phase chemistry}

Table 2 gives representative analyses of the most magnesian olivine phenocrysts and spinel inclusions occurring in our samples.

\subsection{Selecting primitive compositions}

The olivine and spinel compositions provide a means, beyond bulk-rock chemistry, to evaluate the primitive nature of SWC basalts. Before attempting to interpret the phase chemistry in terms of magma source characteristics, it is important to establish the extent to which (1) our samples represent truly primitive liquids and (2) the analyzed olivine-spinel pairs represent the earliest crystallized phases.

The composition of olivine in equilibrium with melt is controlled by the melt $\mathrm{Mg} \#\left[=100 \mathrm{Mg} /\left(\mathrm{Mg}+\mathrm{Fe}^{2+}\right)\right]$ and $\mathrm{K}_{\mathrm{D}}$ value for olivine-melt Fe-Mg equilibrium (e.g., Roeder and Emslie, 1970). To compute Mg\#, it is necessary to know the redox conditions and, specifically, the appropriate $\mathrm{Fe}^{3+} / \Sigma \mathrm{Fe}$ ratio. This parameter was estimated from the $\mathrm{Fe}^{2+} / \mathrm{Fe}^{3+}$ ratio for the most magnesian spinel inclusions analyzed in each sample and the experimentally determined relationship between $\mathrm{Fe}^{2+} / \mathrm{Fe}^{3+}$ in spinel and coexisting melt (cf. Maurel and Maurel, 1983; Larsen and Pedersen, 2000). It is noteworthy that $\mathrm{Fe}^{3+} / \Sigma \mathrm{Fe}$ exhibits a small range ( 0.1 to 0.2 ;average: 0.15 ) for most samples, with Group II samples being only slightly higher, on average, than Group I. A similar range in values is obtained from data for other Cascades basalts (Clynne and Borg, 1997; Conrey et al., 1997). Collectively, these data suggest that Cascades basaltic magmas formed under relatively reduced conditions. Comparison of $\mathrm{Mg \#}$ with maximum Fo content in olivine phenocryst cores (Fig. 4) suggests that olivine compositions are near Fe-Mg equilibrium with liquids represented by the whole-rock compositions for the majority (18 of 28) of our samples. Group II lavas have generally higher whole-rock Mg\# and contain more Fo-rich olivines than Group I lavas.

Ten of the SWC samples examined here fail the above test for equilibrium. Five samples-DS-69A-80, L00-6, L01-5, DS-46-80, and DS-20-80 - contain olivines that plot above the experimentally predicted envelope (Fig. 4) for olivine-melt equilibria (i.e., above the contour for $K_{D}=0.34$ ). An especially enigmatic sample is DS-69A-80, which has such Fe-rich olivines $\left(\mathrm{Fo}_{69-73}\right)$ that it plots off-scale in Fig. 4. Except for DS-20-80, these samples contain spinel inclusions with anomalously high $\mathrm{Fe}^{3+} \#\left(=100 \mathrm{Fe}^{3+}\right.$ / $\left(\mathrm{Fe}^{3+}+\mathrm{Cr}+\mathrm{Al}\right) ; 18$ to 82$)$ compared to most SWC samples (cf. Table 2). To evaluate possible oxidation of these spinels by post-eruptive processes, bulk rock $\mathrm{Mg} \#$ was recalculated using the typical $\mathrm{Fe}^{3+} / \Sigma \mathrm{Fe}$ ratio (0.15). With this correction, one sample (DS-46-80) becomes consistent with olivine-melt equilibria; 
however, the remaining anomalous samples do not, and we conclude that the original magmas were unusually oxidized or that they reflect a more complicated evolutionary history (e.g., involving open system processes). Further work is required to resolve their petrogenesis.

Another sample (DS-23B-81; SHOS-type) contains spinels with high $\mathrm{Fe}^{3+} \#$ as well as high $\mathrm{Fe}_{2} \mathrm{O}_{3}$ contents (cf. Table 2). This rock has relatively low Ni (64 ppm) and Cr (134 ppm) contents and the phenocryst assemblage is complex (cf. Table 1), suggesting an evolved or hybrid nature. In addition, microprobe analyses of clinopyroxene phenocrysts in this rock show evidence (e.g., oscillatory and reverse zoning) for magma mixing and/or assimilation processes. Lastly, when the whole-rock Mg\# is recalculated using $\mathrm{Fe}^{3+} / \sum \mathrm{Fe}=0.15$, this sample plots below the $\mathrm{K}_{\mathrm{D}}=0.26$ contour, suggesting oxidation.

Four other samples contain olivines with higher Fo contents than expected for their Mg\#. These include three from Mount St. Helens (DS-7-, DS-9-, and DS-78-MSH) and one from the frontal arc (L01-11) (cf. Fig. 4). These samples are among the most evolved ones considered here $\left(\mathrm{SiO}_{2}=50.0-54.1 \mathrm{wt} . \%, \mathrm{MgO}=\right.$ 5.89-6.84 wt.\%). As noted above, many Mount St. Helens basalts are considered to be hybrid magmas; their Fo-rich phenocrysts likely are relict crystals formed in a more primitive mixing end member. Sample L01-11 might also be a hybrid magma; it is the only sample analyzed here that contains two populations of core compositions $\left(\mathrm{Fo}_{74-78}\right.$ and $\left.\mathrm{Fo}_{88-89}\right)$, which are separated by a gap of $\sim 10 \mathrm{~mol} \%$ Fo. Neither population plots within the equilibrium $K_{D}$ contours in Fig. 4.

In subsequent discussions of primitive magmatic features, we focus attention on the remaining 18 samples that most closely reflect equilibrium conditions between phenocrysts and bulk lava composition. Although these samples span much of the observed range in bulk composition, they are sparsely porphyritic, show little evidence for shallow storage and cooling, have olivine core compositions $\left(\mathrm{Fo}_{82-88}\right)$ within experimental limits of equilibrium with the bulk rock composition, have high whole-rock $\mathrm{Mg \#}$ (molar $\mathrm{MgO} /\left(\mathrm{MgO}+\mathrm{FeO}^{*}>0.56\right.$, up to 0.67$)$, are characterized by relatively reduced oxidation state (near

QFM-NNO redox buffers), and exhibit internally consistent olivine-melt temperatures. As such, we consider these samples to be among the most primitive known lavas from the SWC region.

\subsection{Significance of spinel compositional variations}

To evaluate the effects of magmatic fractionation on spinel-olivine chemistry, we examined compositional trends of adjacent olivine-spinel pairs occurring within individual phenocrysts (Figs. 5 and 6). Fig. 5 illustrates variations in spinel $\mathrm{Mg} \#\left[=100 \mathrm{Mg} /\left(\mathrm{Mg}+\mathrm{Fe}^{2+}\right)\right]$ and $\mathrm{TiO}_{2}$ with Fo content, from 
cores to rims of single olivine phenocrysts. The observed decrease in $\mathrm{Mg \#}$ (increase in $\mathrm{Fe}^{2+}$ ) and increase in $\mathrm{TiO}_{2}$ in spinel as Fo contents decrease are consistent with solid solution towards magnetite and ülvospinel due to olivine-dominated fractionation. These trends are most likely controlled by spinelliquid equilibria as the spinels are sequentially trapped by the growing olivine host (cf. Luhr and Carmichael, 1985; Clynne, 1993).

Fig. 6 illustrates all available olivine-spinel analyses for seven different samples that were examined in detail. Best-fit lines exhibit trends with positive slopes. Although such trends could be produced by cotectic crystallization of plagioclase plus olivine, this interpretation can be ruled out because phenocrystic plagioclase is lacking in all Group II samples illustrated and in most Group I samples. These trends more likely reflect crystallization of spinel at progressively decreasing pressure during ascent. Experimental data (Roeder and Reynolds, 1991; Jaques and Green, 1980) show that an increase in spinel Cr\# similar to that shown by most of our samples can be produced by a pressure drop from 15 to 2 kbar. In other words, much of the compositional variation seen in spinels from individual samples can be attributed to polybaric crystallization during magma ascent. More importantly, the large differences seen in spinels from the respective Groups I and II are inconsistent with crystallization from a common magma type. Rather, the observed range in spinel composition likely reflects differences in magma chemistry inherited from distinct sources and is partly a consequence of degree of partial melting. These contrasts are amplified by comparing those spinels that have the highest $\mathrm{Mg \#}$ and lowest $\mathrm{Cr} \#$.

To summarize, some of the observed variations in the olivine-spinel pairs in SWC basalts can be attributed to compositional changes due to oxidation, fractionation, mixing, and/or pressure changes during magma evolution. To see through these effects, we consider only olivine-hosted spinels in samples for which olivine-host rock equilibrium can be demonstrated, and for which $\mathrm{Fe}_{2} \mathrm{O}_{3}<16.5$ wt. $\%, \mathrm{Fe}^{3+} \#$ $<22$, and Mg\# is maximal and Cr\# is minimal (cf. Clynne and Borg, 1997). Only the 18 samples for which these criteria are met are plotted in subsequent diagrams (Figs. 7-10) and considered during further discussion of basalt petrogenesis.

\subsection{Magmatic temperatures}

Two methods were used to estimate eruptive temperatures for SWC lavas: (1) thermometry based on MgO-partitioning between olivine cores and silicate melt (Sugawara, 2000); and (2) thermometry based on $\mathrm{CaO} / \mathrm{MgO}$ equilibrium between olivine and melt (Jurewicz and Watson, 1988; cf. Clynne and Borg, 1997). The Sugawara method results in temperatures ranging from 1168 to $1263{ }^{\circ} \mathrm{C}$ assuming anhydrous 
conditions (Table 1). A pressure ( 10 kbar) near the Moho is assumed for these calculations, but the method is fairly insensitive $\left(<5^{\circ} \mathrm{C} / \mathrm{kbar}\right)$ to the value assumed. The calculated temperatures also may be overestimates if the magmas contained significant water; however, actual temperatures will be lower by only $\sim 20{ }^{\circ} \mathrm{C}$ for each wt.\% $\mathrm{H}_{2} \mathrm{O}$ (Ulmer, 2001; Leeman et al., 2004). Considering estimated water contents in comparable lavas from the Northern California Cascades (Sisson and Layne, 1994), corrections (decreases) to the 'anhydrous temperatures' are likely to be small for the relatively dry Group I basalts, but could range up to $\sim 100{ }^{\circ} \mathrm{C}$ for some Group II lavas. Nevertheless, exact corrections for our samples await measurement of $\mathrm{H}_{2} \mathrm{O}$ contents in the respective magmas. Temperatures based on Jurewicz and Watson's work closely mirror the Sugawara temperatures (Table 1), although they are lower by $\sim 20^{\circ} \mathrm{C}$; this difference is well within calibration errors for the two methods. No obvious relationship is observed between temperature and magma type. However, if the geochemistry of Group II lavas (cf. Figs. 2 and 3) correlates with increased $\mathrm{H}_{2} \mathrm{O}$, then actual temperatures for some Group II lavas could be significantly lower than our estimates. Nearly all Group I lavas have estimated eruptive temperatures in excess of $\sim 1200{ }^{\circ} \mathrm{C}$, implying very warm conditions in the underlying mantle. The companion paper by Leeman et al. (2005) in this volume addresses this issue in more detail.

\subsection{Pressure estimates}

Primitive spinel and host rock compositions were used in equilibria calculations via the method of Allan et al. (1988; cf. Clynne and Borg, 1997) to constrain pressures of crystallization. Although these determinations are imprecise, SWC spinels contain excess Al relative to low-pressure spinels from other localities and are similar to those in mantle xenoliths and lavas interpreted to have crystallized at relatively high pressure (>5 kbar; cf. Fig. 8 in Clynne and Borg, 1997); this result is consistent with our interpretation of polybaric crystallization (cf. Section 5.2). Leeman et al. (2005) estimate and discuss mantle segregation depths for calculated parental magmas; Group I lavas (and particularly the LKT variants) appear to segregate from higher pressures $(14.6 \pm 3.7 \mathrm{~kb})$ than Group II lavas $(10.2 \pm 2.5 \mathrm{~kb})$. Elkins-Tanton et al. (2001) derive similar estimates for LKT basalts from northern California.

\subsection{Compositional characteristics of SWC primitive spinels}

Based on data for the most primitive spinels and olivines in the 18 selected samples, several important relationships are evident:

(1) Fo contents of the olivine hosts immediately adjacent to analyzed spinel inclusions range from 82 to 
88 (Fig. 7); olivines in Group II lavas are somewhat more Mg-rich than those in Group I lavas.

(2) Spinel inclusions encapsulated within olivine hosts exhibit a wide range of Cr\# (from 20 to 57; Figs. $7 \mathrm{~A}$ and $8 \mathrm{~B}$ ) and $\mathrm{Al}_{2} \mathrm{O}_{3}$ contents (from16.6 to 46.3 wt.\%).

(3) Spinel Cr\# for Group I lavas are systematically lower $(<41)$ than those ( $>45)$ for Group II lavas (Figs. $7 \mathrm{~A}$ and $8 \mathrm{~B})$

(4) Spinel Mg\# ranges from 45 to 71 (Figs. 7C-D and 8A). Although these values overlap for Group I and II, each group defines distinct clusters on plots of Mg\# against spinel Cr\# or olivine Fo (Figs. 7B and $8 \mathrm{~A})$.

(5) Although no clear trend is observed in $\mathrm{Fe}^{2+} / \Sigma \mathrm{Fe}$ vs. $\mathrm{Mg} \#$ in Group I spinels, Group II lavas have generally lower $\mathrm{Fe}^{2+} / \Sigma \mathrm{Fe}$ (i.e., higher $\mathrm{Fe}^{3+}$ ) than most Group I lavas (Fig. 7D).

(6) It is not possible to distinguish among spinels in lava subtypes (e.g., ALK vs. OIB vs. LKT) within either Group I or II.

Our results are similar to what has been observed in lavas of the Lassen region (northern California). Although more primitive (in accord with generally higher whole-rock Mg\#s), spinels in Lassen basalts are compositionally similar to those in SWC basalts. Spinels in basalts from the Oregon High Cascades (Conrey et al., 1997) and additional samples from the vicinity of Mt. Adams (Hildreth and Fierstein, 1997) are likewise similar to the results reported here.

Fig. 8B compares $\mathrm{Al}_{2} \mathrm{O}_{3}$ and $\mathrm{TiO}_{2}$ contents for spinels in $\mathrm{SWC}$ basalts with those for spinels occurring in a variety of tectonic environments (cf. Kamenetsky et al., 2001). Groups I and II define distinct fields in this diagram. Interestingly, all available SWC spinel data plot in the field for mid-ocean ridge basalts rather than that for typical arc lavas. As the diagram depends heavily on data for western Pacific volcanic arcs, this apparent anomaly may reflect differences in the sub-arc mantle possibly due to different melting histories.

\section{Discussion and conclusions}

The mineral and whole-rock chemical data reported here suggest an origin for SWC basalts via melting of heterogeneous domains in the sub-arc mantle. Albeit some variations within the general population of olivine-spinel pairs of SWC basalts can be attributed to variations in $f \mathrm{O}_{2}$, fractionation, mixing, and/or pressure changes during magma evolution (cf. Section 5.2), the impact of these parameters on spinel Cr\# are relatively small (Clynne and Borg, 1997) and cannot account for variations between primitive spinels 
in Groups I and II.

The mantle array for coexisting olivine and spinel (Arai, 1994, cf. Figs. 6 and 7B) illustrates that spinel $\mathrm{Cr} \#$ and olivine Fo contents increase as peridotite sources become more refractory. For example, depleted harzburgites contain spinels with higher $\mathrm{Cr} \#$ than fertile spinel lherzolites and pyroxenites (Dick and Fisher, 1984). Minor variations ( $5 \%$ to $10 \%)$ in degree of partial melting of either fertile or depleted sources can explain the small ranges in spinel Cr\# within either Group I or Group II. However, distinctly higher spinel Cr\# for Group II lavas (Fig. 7A) require unrealistically large degrees of partial melting if they are to be derived from the same source generating Group I lavas. We suggest instead higher Cr\# for Group II spinels indicate derivation of Group II magmas from more refractory sources than Group I. The somewhat higher average Fo (87 vs. 84 wt.\%) and $\mathrm{NiO}$ (0.33 vs. 0.23 wt.\%) contents of olivines in Group II vs. Group I lavas provide further evidence for this view, as do whole-rock geochemical features for Group II, e.g., generally higher $\mathrm{Mg} \#$ (Fig. 4), and lower $\mathrm{FeO}^{*}$ and $\mathrm{Al}_{2} \mathrm{O}_{3}$ (Fig. 9E-F).

The "within-plate"-like chemistry of most Group I lavas (cf. Fig. 3A) precludes significant slab-derived contributions and is consistent with upwelling and decompression melting of little modified and relatively fertile mantle wedge material, as originally suggested by Leeman et al. (1990). Large ion lithophile and fluid-mobile element enrichments in Group II lavas (e.g., Fig. 9A-B) are, in principle, related to influx of slab fluids that enrich these elements in portions of the mantle wedge proximal to the subducting slab (cf. Pearce and Peate, 1995), and melting may be triggered by influx of such fluids (cf. Reiners et al., 2000). Lower $\mathrm{Fe}^{2+} / \sum \mathrm{Fe}$ ratios in Group II compared to Group I spinels (cf. Fig. 7D) are consistent with crystallization from slightly more oxidized magmas derived from a fluid-metasomatized mantle source. However, beryllium isotopic and trace element data for Quaternary SWC basalts (Morris and Tera, 1989; Leeman et al., 1990) imply that the slab may have been largely dehydrated by the time it reached sub-arc mantle depths. Only basalts from the frontal part of the arc exhibit elevated concentrations of fluidmobile elements indicative of significant slab contributions to the overlying mantle and, compared to most other arcs, the observed enrichments are weak (cf. Ryan et al., 1995, 1996). Given this apparent lack of modern fluid fluxing, an alternative interpretation for Group II magmas is that they represent melts of "fossil" metasomatized source domains within the sub-arc lithospheric mantle. Fluid fluxing and mobile element enrichment could have occurred anytime in the 40 Myr duration of Cascadia subduction. The influx of hot, decompression magmas (Group I) could cause reheating and anatexis of these metasomatized domains. This scenario involves two (or more) distinct processes of melt production and at least two mantle sources, each of which may be internally heterogeneous. 
A noteworthy feature is the close temporal and spatial occurrence of SWC primitive basalts. All of the lavas studied here are young ( 1 Ma). At Mount St. Helens and within the Indian Heaven lava field, lavas from both Groups I and II issued from either the same or proximal vents. Given this observation and the whole-rock and mineral chemistry, we infer that mantle sources beneath the SWC arc are heterogeneous on the scale of local plumbing systems. Fig. 10 illustrates that there is no clear relationship between the phase chemistry of primitive SWC basalts and their location across the arc. Additional studies are required to address (1) the spatial distribution of magma sources (e.g., is the mantle heterogeneous on a small scale or is it stratified/layered on a large scale?), and (2) the viability of re-melting fossil metasomatized domains within either shallow mantle wedges or lithospheric mantle.

If real, the distinction of two 'flavors' of mantle source, with different degrees of fertility and broad distribution beneath the arc, suggests the need for a different perspective on arc magmatism. Clynne and Borg (1997) and Borg et al. (1997) also observed differences in degree of mantle fertility beneath the northern California Cascades. However, they inferred the presence of more depleted sources nearer the frontal arc region and proposed that the observed spatial variation resulted from progressive meltdepletion of convecting wedge mantle. We also observe lavas indicative of depleted sources near the arc front, but additionally find some frontal arc lavas to be derived from relatively fertile (OIB-like) sources-implying that depleted sources cannot simply reflect a progressive depletion process. Our results also preclude a simple flux melting model (e.g., Reiners et al., 2000) to produce the observed compositional spectrum from an initially homogeneous mantle source.

The unusually warm nature of the Cascadia subduction zone may be an important factor in showcasing diversity in mantle wedge composition. Perhaps the absence of a strong slab-flux signature prevents ubiquitous overprinting of the wedge mantle chemistry, such that inherent heterogeneities can be preserved during melting processes. In contrast, elevated flux levels in cooler subduction zones may cause flux melting processes to dominate and generate the geochemical characteristics widely considered 'typical' for volcanic arcs.

\section{Acknowledgements}

DRS thanks Drs. David Wark and Kitty Milliken for access to and assistance with the microprobe facilities at RPI and UT-Austin, respectively, and Trinity University for financial support. We thank Dr. V.S. Kamenetsky (Univ. of Tasmania) for providing additional microprobe analyses and sharing his 
expertise in spinel chemistry. We thank Russ Evarts for his assistance in collecting some of the samples described in this paper and sharing his insights on Cascades volcanism. We thank Michael Clynne and Nathan Green for their very thoughtful and helpful reviews. This work was supported by National Science Foundation grant EAR-0003612 to WPL.

\section{References}

Albarède, F., 1992. How deep do common basaltic magmas form and differentiate? Journal of Geophysical Research 97, 10997 - 11009.

Allan, J.F., Sack, R.O., Batiza, R., 1988. Cr-rich spinels as petrogenetic indicators; MORB-type lavas from the Lamont seamount chain, eastern Pacific. American Mineralogist 73, $741-753$.

Arai, S., 1994. Compositional variation of olivine-chromian spinel in Mg-rich magmas as a guide to their residual spinel peridotites. Journal of Volcanology and Geothermal Research 59, 279 - 293.

Bacon, C.R., Bruggman, P.E., Christiansen, R.L., Clynne, M.A., Donnelly-Nolan, J.M., Hildreth, W., 1997. Primitive magmas at five Cascade volcanic fields; melts from hot, heterogeneous sub-arc mantle. Canadian Mineralogist 35, 397 - 423.

Baker, M.B., Stolper, E.M., 1994. Determining the composition of high-pressure mantle melts using diamond aggregates. Geochimica et Cosmochimica Acta 58, 2811 - 2827.

Ballhaus, C., Berry, R.F., Green, D.H., 1991. High pressure experimental calibration of the olivineorthopyroxene-spinal oxygen geobarometer: implications for the oxidation state of the upper mantle. Contributions to Mineralogy and Petrology 107, 27 - 40.

Borg, L.E., Clynne, M.A., Bullen, T.D., 1997. The variable role of slab-derived fluids in the generation of a suite of primitive calc- alkaline lavas from the southernmost Cascades, California. Canadian Mineralogist 35, $425-452$.

Chulick, G., Mooney, W.D., Detweiler, S.T., 2001. Crustal structure of North America and the adjacent ocean basins. Abstracts with Programs, Geological Society of America 33 (6), 299. 
Clynne, M.A., 1993. Geologic studies of the Lassen volcanic center, Cascade Range, California. PhD Thesis, University of California-Santa Cruz, Santa Cruz, CA.

Clynne, M.A., Borg, L.E., 1997. Olivine and chromian spinel in primitive calc-alkaline and tholeiitic lavas from the southern-most Cascade Range, California: a reflection of relative fertility of the source. Canadian Mineralogist 35, 453 - 472.

Conrey, R.M., Sherrod, D.R., 2003. Longevity and spacing of Cascade stratocones. State of the Arc Conference Abstract, URL: http://www.terra.rice.edu/sota/papers/Conrey,RickLongevity_abst.doc.

Conrey, R.M., Sherrod, D.R., Hooper, P.R., Swanson, D.A., 1997. Diverse primitive magmas in the Cascade arc, northern Oregon and southern Washington. Canadian Mineralogist 35, 367 - 396.

Currie, C.A., Wang, K., Hyndman, R.D., He, J., 2003. A hot mantle wedge and backarc at the Cascadia subduction zone: numerical tests using a model of slab-driven wedge flow. Abstracts with Programs, Geological Society of America 35, 644.

Dick, H.J.B., 1989. Abyssal peridotites, very slow spreading ridges and ocean ridge magmatism. In: Saunders, A.D., Norry, M.J. (Eds.), Magmatism in the Ocean Basins. Special Publication Geological Society vol. 42 , pp. $71-209$.

Dick, H.J.B., Bullen, T.D., 1984. Chromian spinal as a petrogenetic indicator in abyssal and alpine-type peridotites and spatially associated lavas. Contributions to Mineralogy and Petrology 6, $43-76$.

Dick, H.J.B., Fisher, R.L., 1984. Mineralogic studies of the residues of mantle melting: abyssal and alpine-type perioditites. In: Kornprobst, J. (Ed.), Kimberlites II. The Mantle and Crust-Mantle Relationships. Elsevier, Amsterdam, pp. 295 - 308.

Elkins-Tanton, L.T., Grove, T.L., Donnelly-Nolan, J., 2001. Hot, shallow mantle melting under the Cascades volcanic arc. Geology 29, $631-634$.

Evarts, R.C., Clynne, M.A., Fleck, R.J., Lanphere, M.A., Calvert, A.T., Sarna-Wojcicki, A.M., 2003. The antiquity of Mount St. Helens and age of the Hayden creek drift. Abstracts with Programs Geological Society of America 35 (6), 80. 
Fleck, R.J., Evarts, R.C., Hagstrum, J.T., Valentine, M.J., 2002. The Boring volcanic field of the Portland, Oregon area; geochronol- ogy and neotectonic significance. Abstracts with Programs Geological Society of America 34 (5), 33 - 34.

Fujii, T., 1989. Genesis of mid-ocean ridge basalts. In: Saunders, A.D., Norry, M.J. (Eds.), Magmatism in the Ocean Basins, Special Publication Geological Society 42, 137 - 146.

Green, N.L., Harry, D.L., 1999. On the relationship between subducted slab age and arc basalt petrogenesis, Cascadia subduction system, North America. Earth and Planetary Science Letters 171, 367381.

Guffanti, M., Weaver, C.S., 1988. Distribution of late Cenozoic volcanic vents in the Cascade Range; volcanic arc segmentation and regional tectonic considerations. Journal of Geophysical Research, B 93, $6513-6529$.

Hammond, P.E., Korosec, M.A., 1983. Geochemical analyses, age dates, and flow-volume estimates for Quaternary volcanic rocks, southern Cascades Mountains, Washington. Washington State Division of Geology and Earth Resources. Open File Report 83-13, 36 pp.

Hildreth, W., Fierstein, J., 1997. Recent eruptions of Mount Adams, Washington Cascades, USA. Bulletin of Volcanology 58, $472-490$.

Hoblitt, R.P., Crandell, D.R., Mullineaux, D.R., 1980. Mount St. Helens eruptive behavior during the past 1,500 yr. Geology 8, $555-559$.

Hoblitt, R.P., Miller, C.D., Scott, W.E., 1987. Volcanic hazards with regard to siting nuclear-power plants in the Pacific Northwest. U.S. Geological Survey Open-File Report 87-297, 196 pp.

Hyndman, R.D., Wang, K., 1993. Thermal constraints on the zone of major thrust earthquake failure: the Cascadia subduction zone. Journal of Geophysical Research, B 98, 2029 - 2060.

Jaques, A.L., Green, T.H., 1980. Anhydrous partial melting of peridotite at $0-15 \mathrm{~Kb}$ pressure and the genesis of tholeiitic basalts. Contributions to Mineralogy and Petrology 73, $287-310$. 
Jurewicz, A.J.G., Watson, E.B., 1988. Cations in olivine: 1. Calcium partitioning and calciummagnesium distribution between olivines and coexisting melts, with petrologic applications. Contributions to Mineralogy and Petrology 99, 176 - 185.

Kamenetsky, V.S., Crawford, A.J., Meffre, S., 2001. Factors controlling chemistry of magmatic spinel: an empirical study of associated olivine, $\mathrm{Cr}$-spinel and melt inclusions from primitive rocks. Journal of Petrology 42, $655-671$.

Larsen, L.M., Pedersen, A.K., 2000. Processes in high-Mg, high-T magmas: evidence from olivine, chromite and glass in Paleogene picrites from west Greenland. Journal of Petrology 41, $1071-1098$.

Leeman, W.P., Smith, D.R., Hildreth, W., Palacz, Z., Rogers, N., 1990. Compositional diversity of Late Cenozoic basalts in a transect across the southern Washington Cascades: implications for subduction zone magmatism. Journal of Geophysical Research, B 95, 19561 - 19582.

Leeman, W.P., Lewis, J.F., Evarts, R.C., Conrey, R.M., Streck, M.A., 2005. Petrologic constraints on the thermal structure of the Cascades arc. Journal of Volcanology and Geothermal Research 140, 67-105 (this volume). doi:10.1016/ j.jvolgeores.2004.07.016.

Lewis, J., Leeman, W.P., Evarts, R.C., 2001. Petrological constraints on the thermal structure of the southern Washington Cascades. EOS Transactions American Geophysical Union 82, 1301.

Luhr, J.F., Carmichael, I.S.E., 1985. Jorullo volcano, Michoacán, Mexico (1759-1774): the earliest stages of fractionation in calc-alkaline magmas. Contributions to Mineralogy and Petrology 90, 142-161.

Matsukage, K.N., Kubo, K., 2003. Chromian spinel during melting experiments of dry peridotites (KLB1) at 1.0-2.5 GPa. American Mineralogist 88, $1271-1278$.

Maurel, C., Maurel, P., 1983. Étude expérimentale de l'équilibre $\mathrm{Fe}^{2+}-\mathrm{Fe}^{3+}$ dans les spinelles chromifères et les liquides silicatés basiques coexistants, à 1 atm. Comptes Rendus de l'Académie des Sciences 295, $209-212$.

McCrory, P.A., 1996. Tectonic model explaining divergent contraction directions along the Cascadia 
subduction margin, Washington. Geology 24, $929-932$.

Michaelson, C.A., Weaver, C.S., 1986. Upper mantle structure from teleseismic P wave arrivals in Washington and northern Oregon. Journal of Geophysical Research, B 91, 2077 - 2094.

Mooney, W.D., Weaver, C.S., 1989. Regional crustal structure and tectonics of the Pacific coastal states; California, Oregon, and Washington. In: Pakiser, L.C., Mooney, W.D. (Eds.), Geophysical Framework of the Continental United States. Memoir Geological Society of America 172, 129 - 161.

Morris, J.D., Tera, F., 1989. ${ }^{10} \mathrm{Be}$ and ${ }^{9} \mathrm{Be}$ in mineral separates and whole rocks from volcanic arcs: implications for sediment subduction. Geochimica et Cosmochimica Acta 53, 3197 - 3206.

Mullineaux, D.R., 1996. Pre-1980 tephra-fall deposits erupted from Mount St. Helens, Washington. U.S. Geological Survey Professional Paper 1563, 99 pp.

Natland, J.H., Adamson, A.C., Laverne, C., Melson, W.G., O’Hearn, T., 1983. A compositionally nearly steady-state magma chamber at the Costa Rica Rift: evidence from basalt glass and mineral data. Initial Reports, Deep-Sea Drilling Project 69, 811 - 858.

Peacock, S.M., Leeman, W.P., 1994. Thermal/petrologic evolution of the Cascadia subduction zone. EOS Transactions American Geophysical Union 75, 621.

Pearce, J.A., Peate, D.W., 1995. Tectonic implications of the composition of volcanic arc magmas. Annual Review of Earth and Planetary Sciences 23, 251 - 285.

Reiners, P.W., Hammond, P.E., McKenna, J.M., Duncan, R.A., 2000. Young basalts of the central Washington Cascades, flux melting of the mantle, and trace element signatures of primary arc magmas. Contributions to Mineralogy and Petrology 138, 249 - 264.

Riddihough, R.P., 1984. Recent movements of the Juan de Fuca Plate system. Journal of Geophysical Research, B 89, 6980 - 6994.

Roeder, P.L., 1994. Chromite: from the fiery rain of chondrules to Kilauea Iki lava lake. Canadian Mineralogist 32, $729-746$. 
Roeder, P.L., Emslie, R.F., 1970. Olivine-liquid equilibrium. Contributions to Mineralogy and Petrology $29,276-289$.

Roeder, P.L, Reynolds, I., 1991. Crystallization of chromite and chromium solubility in basaltic melts. Journal of Petrology 32, 909 - 934.

Romanyuk, T.V., Blakely, R.J., Mooney, W.D., 1998. The Cascadia subduction zone; two contrasting models of lithospheric structure. Physics and Chemistry of the Earth 23 (3), 297 - 301.

Ryan, J.G., Morris, J., Tera, F., Leeman, W.P., Tsvetkof, A., 1995. Cross-arc geochemical variations in the Kurile arc as a function of slab depth. Science 270, $625-628$.

Ryan, J., Morris, J., Bebout, G., Leeman, B., 1996. Describing chemical fluxes in subduction zones: insights from "depth-profiling" studies of arc and forearc rocks. In: Bebout, G.E., Scholl, D., Kirby, S., Platt, J.P. (Eds.), Subduction Top to Bottom. American Geophysical Union Monograph 96, 263 - 268.

Sherrod, D.R., Smith, J.G., 2000. Geologic map of upper Eocene to Holocene volcanic and related rocks of the Cascade Range, Oregon. U.S. Geological Survey Geologic Investigations Series I-2569, $1: 500,000$.

Sigurdsson, H., Schilling, J.-G., 1976. Spinels in Mid-Atlantic Ridge basalts: chemistry and occurrence. Earth and Planetary Science Letters 29, 7 - 20.

Sisson, T.W., Layne, G., 1994. $\mathrm{H}_{2} \mathrm{O}$ in basalt and basaltic andesite glass inclusions from four subductionrelated volcanoes. Earth and Planetary Science Letters 117, 619 - 635.

Smith, D.R., Leeman, W.P., 1987. Petrogenesis of Mount St. Helens dacitic magmas. Journal of Geophysical Research, B 92, 10313 - 10334.

Smith, D.R., Leeman, W.P., 1993. The origin of Mount St. Helens andesites. Journal of Volcanology and Geothermal Research 55, 271 - 303. 
Stormer, J.C., 1983. The effects of recalculation on estimates of temperature and oxygen fugacity from analyses of multi- component iron-titanium oxides. American Mineralogist 68, 586 - 594.

Sugawara, T., 2000. Empirical relationships between temperature, pressure, and $\mathrm{MgO}$ content in olivine and pyroxene saturated liquids. Journal of Geophysical Research, B 105, 8457 - 8472.

Sun, S.S., McDonough, W.F., 1989. Chemical and isotopic systematics of oceanic basalts: implications for mantle composition and processes. In: Saunders, A.D., Norry, M.J. (Eds.), Magmatism in the Ocean Basins, Special Publication Geological Society 42, 313 - 334.

Swanson, D.A., Cameron, K.A., Evarts, R.C., Pringle, P.T., Vance, J.A., 1989. Cenozoic volcanism in the Cascade Range and Columbia Plateau, southern Washington and northernmost Oregon. Memoir New Mexico Bureau of Mines \& Mineral Resources 47, 1 - 50.

Thy, P., 1983. Spinel minerals in transitional and alkali basaltic glasses from Iceland. Contributions to Mineralogy and Petrology 83, $141-149$.

Thy, P., 1995. Experimental constraints on the evolution of transitional and mildly alkalic basalts; crystallization of spinel. Lithos $36,103-114$.

Ulmer, P., 2001. Partial melting in the mantle wedge; the role of $\mathrm{H}_{2} \mathrm{O}$ in the genesis of mantle-derived 'arc-related' magmas. Physics of the Earth and Planetary Interiors 127, 215 - 232.

Verplanck, E.P., Duncan, R.A., 1987. Temporal variations in plate convergence and eruption rates in the Western Cascades, Oregon. Tectonics 6, 197 - 209.

Wang, K., Wells, R., Mazzotti, S., Hyndman, R.D., Sagiya, T., 2003. A revised dislocation model of interseismic deformation of the Cascadia subduction zone. Journal of Geophysical Research 108 (B1). doi:10.1029/2001JB001227.

Wasylenki, L.E., Baker, M.B., Kent, A.J.R., Stolper, E.M., 2003. Near-solidus melting of the shallow upper mantle: partial melting experiments on depleted peridotite. Journal of Petrology 44, 1163 - 1191.

Weaver, C.S., Michaelson, C.A., 1985. Seismicity and volcanism in the Pacific Northwest: evidence for 
the segmentation of the Juan de Fuca plate. Geophysical Research Letters 12, 215 - 218.

Wells, R.E., Weaver, C.S., Blakely, R.J., 1999. Microplate motions and neotectonics of the Cascadia forearc. Seismological Research Letters 70, 209.

Zoback, M.L., Zoback, M.D., 1980. State of stress in the conterminous United States. Journal of Geophysical Research, B 85, 6113-6156.

Figure 1:

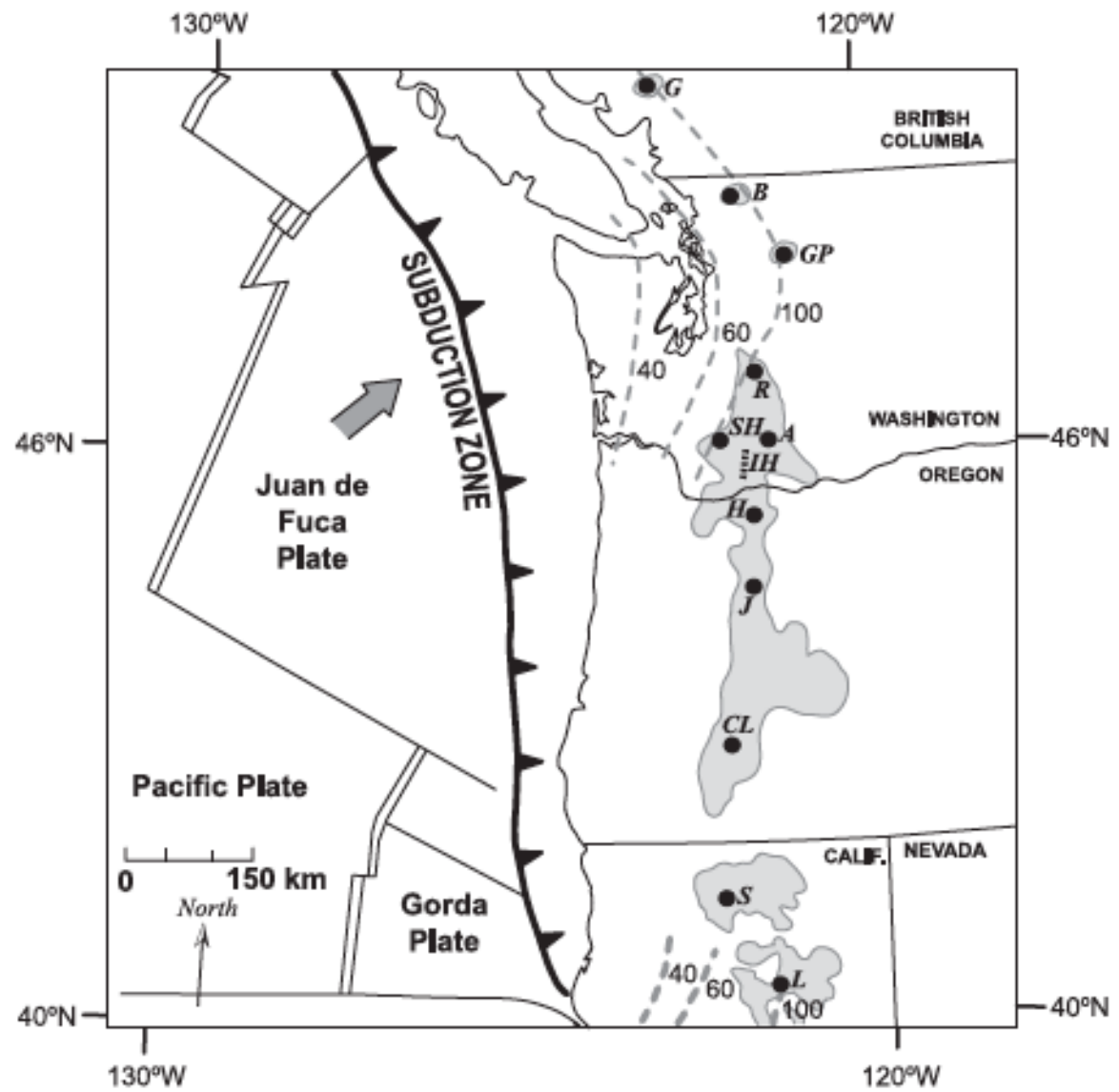

Fig. 1. Location map showing extent of High Cascades volcanic cover (shaded areas) and major Cascade stratovolcanoes (black dots) and plate tectonic features (after Guffanti and Weaver, 1988; Romanyuk et al., 1998). The Indian Heaven (IH) lava field is indicated by short dashed line. G, Mount Garibaldi; B, Mount Baker; GP, Glacier Peak; R, Mount Rainier, SH, Mount St. Helens; A, Mount Adams; H, Mount Hood; J, Mount Jefferson; CL, Crater Lake, S, Mount Shasta; L, Lassen Peak. The 40-, 60-, and 100-km contours (dashed lines) indicate depth to the subducted slab (Michaelson and Weaver, 1986; Romanyuk et al., 1998). 
Table 1:

Table 1

Sample information, including magna type, latitude, longitude, phenocryst population, major (in wL\% oxide) and selected trace element (in pom) abundances, and estimaled enuptive temperatures

\begin{tabular}{|c|c|c|c|c|c|c|c|c|c|c|c|c|c|c|c|c|c|c|c|c|c|c|c|}
\hline Sample no. & $\begin{array}{l}\text { Magma } \\
\text { type }\end{array}$ & $\begin{array}{l}\text { General } \\
\text { location }^{b}\end{array}$ & Latitude & Longitude & $\begin{array}{l}\text { Phenocryst } \\
\text { populationf }\end{array}$ & $\mathrm{SH}_{2}$ & $\mathrm{TiO}_{2}$ & $\mathrm{Al}_{2} \mathrm{O}_{3}$ & $\mathrm{FeO}{ }^{*}$ & $\mathrm{MnO}$ & $\mathrm{MgO}$ & $\cos$ & $\mathrm{Na}_{2} \mathrm{O}$ & $\mathrm{K} \neq \mathrm{O}$ & $\mathrm{P}_{2} \mathrm{O}_{5}$ & $\mathrm{Ni}$ & $\mathrm{Cr}$ & St & $\mathrm{Ba}$ & $\mathrm{Y}$ & $\mathrm{Z}_{\mathrm{r}}$ & $\begin{array}{l}\text { T, J and } \\
\text { W' } 88\end{array}$ & $\mathrm{~T}, \mathrm{~S}^{\prime} 00$ \\
\hline $00-14$ & LKT & IH & 45.913 & -121.701 & olttr.pl & 50.80 & 1.19 & 16.86 & 9.65 & 0.16 & 8.15 & 9.52 & 3.10 & 0.41 & 0.15 & 108 & 266 & 300 & 106 & 22 & 95 & 1215 & 1227 \\
\hline DS-6A-80 & LKT & IH & 45.914 & -121.699 & ol & 50.59 & 1.14 & 1730 & 9.51 & 0.16 & 8.21 & 9.34 & 3.15 & 0.39 & 0.22 & 108 & 280 & 291 & 98 & 20.7 & 99 & 1215 & 1229 \\
\hline DS- 80 A- -80 & LKT & IH & 45.879 & -121.518 & oHtpl & 48.30 & 1.16 & 17.50 & 10.98 & 0.18 & 8.37 & 9.89 & 3.23 & 0.22 & 0.16 & 110 & 208 & 259 & 63 & 18.8 & 75 & 1220 & 1250 \\
\hline$S-41-81$ & LKT & IH & 46.017 & -121.776 & ofttrpl & 49.59 & 1.07 & 1730 & 10.20 & 0.17 & 8.40 & 9.57 & 3.08 & 0.43 & 0.20 & 129 & 252 & 371 & 124 & 23.1 & 90 & 1220 & 1241 \\
\hline L00-24 & LKT & MA & 46.326 & -121.501 & oltpl & 48.95 & 1.52 & 16.82 & 10.69 & 0.17 & 7.89 & 10.40 & 3.04 & 0.33 & 0.17 & 103 & 252 & 282 & 76 & 24.8 & 111 & 1190 & 1234 \\
\hline DS-78-MSH & OIB & MSH & 46.229 & -122.187 & oltpl & 52.20 & 1.54 & 17.30 & 9.66 & 0.13 & 5.89 & 7.94 & 4.04 & 1.00 & 0.29 & 76 & 152 & 514 & 262 & & 178 & N.C. & N.C. \\
\hline DS-4-MSH & OIB & MSH & 46.221 & -122.167 & oltpl & 51.77 & 1.73 & 17.74 & 8.53 & 0.13 & 6.19 & 8.30 & 4.24 & 1.17 & 0.20 & 80 & 169 & 581 & 275 & 17.5 & 188 & 1165 & 1177 \\
\hline DS-69A-80 & OIB & IH & 46.055 & -121.565 & ol & 52.37 & 1.40 & 16.79 & 8.08 & 0.14 & 792 & 8.38 & 3.62 & 0.94 & 0.37 & 186 & 373 & $\$ 69$ & 268 & 19.1 & 157 & N.C. & N.C. \\
\hline DS $-46-80$ & OBB & IH & 46.117 & -121.771 & oltpl & 50.31 & 1.50 & 17.10 & 9.52 & 0.16 & 6.89 & 10.14 & 3.15 & 0.97 & 0.25 & 74 & 192 & $\$ 43$ & 267 & 23.6 & 161 & N.C. & N.C. \\
\hline DS-2A- 80 & OIB & IH & 45.936 & -121.82 & ol & 52.33 & 1.56 & 17.31 & 8.60 & 0.15 & 6.63 & 8.29 & 3.85 & 0.92 & 0.35 & 90 & 184 & $\$ 54$ & 268 & 21.9 & 174 & 1185 & 1184 \\
\hline DS-20-80 & OIB & IH & 46.052 & -121.843 & ol & 52.21 & 1.44 & 16.80 & 8.21 & 0.14 & 7.71 & 8.57 & 3.55 & 1.07 & 0.30 & 146 & 264 & $\$ 62$ & 240 & 16.4 & 151 & N.C. & N.C. \\
\hline DS-26A-80 & OIB & IH & 45.938 & -121.854 & ol & 49.33 & 1.40 & 17.61 & 9.32 & 0.16 & 8.33 & 9.65 & 3.23 & 0.70 & 0.27 & 158 & 356 & 483 & 219 & 22.2 & 138 & 1215 & 1240 \\
\hline L01-24 & OIB & MA & 45.974 & -121.393 & ofttr.cpx & 51.55 & 1.42 & 16.76 & 8.95 & 0.15 & 7.54 & 8.99 & 3.49 & 0.84 & 0.31 & 123 & 227 & 582 & 238 & 23 & 151 & 1200 & 1209 \\
\hline $01-25$ & OIB & MA & 46.056 & -121.325 & olttr.cpx+tr.plag & 51.85 & 1.34 & 16.99 & 9.20 & 0.16 & 7.50 & 8.71 & 3.33 & 0.64 & 0.28 & 124 & 214 & 450 & 235 & 23 & 139 & 1205 & 1207 \\
\hline L00-8 & ALK & $\mathrm{FA}$ & 45.826 & -122.501 & oHtmp.cpx & 49.62 & 2.00 & 1658 & 9.06 & 0.15 & 7.90 & 9.35 & 3.40 & 1.40 & 0.55 & 123 & 220 & 841 & 355 & 21 & 193 & 1210 & 1228 \\
\hline L01-17 & ALK & MSH & 46.211 & -122.249 & oltmp.pl & 51.82 & 1.76 & 16.93 & 9.15 & 0.14 & 6.57 & 8.39 & 3.87 & 1.00 & 0.36 & 95 & 180 & 513 & 299 & 24 & 157 & 1185 & 1186 \\
\hline S-7-MSH & ALK & MSH & 46.221 & -122.167 & oltpl & 50.02 & 1.98 & 16.28 & 10.55 & 0.15 & 6.84 & 8.55 & 3.91 & 1.34 & 0.38 & 81 & 157 & 577 & 319 & & 203 & N.C. & N.C. \\
\hline DS-9-MSH & ALK & MSH & 46.221 & -122.167 & olt pl & 48.99 & 2.10 & 16.70 & 11.14 & 0.15 & 6.68 & 8.72 & 3.79 & 1.36 & 0.37 & 84 & 155 & $\$ 90$ & 312 & 26.2 & 200 & N.C. & N.C. \\
\hline L01-3b & $\mathrm{CA}$ & $\mathrm{FA}$ & 46.083 & -122.367 & oftcpx & 50.66 & 1.24 & 15.82 & 790 & 0.13 & 8.46 & 9.84 & 3.30 & 2.11 & 0.54 & 130 & 259 & 1789 & 737 & 19 & 180 & 1215 & 1234 \\
\hline 006 & $\mathrm{CA}$ & $\mathrm{FA}$ & 46.019 & -122.44 & & 49.78 & 1.15 & 15.75 & 8.28 & 0.14 & 9.51 & 10.70 & 282 & 1.49 & 0.37 & 137 & 350 & 1309 & 507 & 19.4 & 179 & N.C. & N.C. \\
\hline L01-6 & CA & $\mathrm{FA}$ & 46.026 & -122.42 & oltmp.cpx & 49.64 & 1.14 & 17.04 & 8.74 & 0.15 & 9.43 & 9.87 & 295 & 0.82 & 0.22 & 131 & 364 & 849 & 399 & 20 & 130 & 1230 & 1263 \\
\hline $1-21$ & CA & MA & 46.347 & & oltmp.cpx & 50.40 & 1.30 & 16.49 & 8.40 & 0.14 & 8.52 & 9.74 & 3.31 & 1.26 & 0.42 & & & & & & & 1215 & 1237 \\
\hline L01-23 & CA & MA & 5.026 & 121.497 & $\mathrm{oH}+\mathrm{m}$ & 50.25 & 1.48 & 16.19 & 8.68 & 0.15 & 8.79 & 9.43 & 3.54 & 1.11 & 0.37 & 169 & 294 & 936 & 326 & 20 & 142 & 1230 & 1244 \\
\hline L00-10 & BA & $\mathrm{FA}$ & 45.541 & -122.564 & oft mp.cpx & 54.39 & 1.23 & 17.41 & 7.18 & 0.12 & 6.24 & 7.82 & 4.10 & 1.17 & 0.35 & 129.5 & 179 & 837 & 357 & 18 & 168.5 & 1178 & 1168 \\
\hline L01-5 & $\mathrm{BA}$ & $\mathrm{FA}$ & 46.085 & -122.415 & & 53.69 & 0.97 & 16.51 & 730 & 0.12 & 8.30 & 8.37 & 3.79 & 0.75 & 0.20 & 172 & 350 & 638 & 198 & 18 & 111 & N.C. & N.C. \\
\hline & BA & FA & 629 & 2.142 & oltmp.cpx + & $\$ 4.13$ & 1.13 & 17.40 & 737 & 0.13 & 6.66 & 8.11 & 3.91 & 0.88 & 0.29 & 126 & 199 & 669 & 228 & 16 & 131 & N.C. & N.C. \\
\hline & SHOS & IH & 46.037 & -121.766 & ol & $\$ 2.70$ & 1.13 & 16.00 & 736 & 0.12 & 8.41 & 8.49 & 3.62 & 1.74 & 0.43 & 183 & 334 & 1058 & 563 & 14.7 & 184 & 1230 & 1222 \\
\hline DS-23B-81 & SHOS & IH & 45.972 & -121.804 & olt cpxt plt tamph & 52.19 & 1.32 & 16.90 & 7.65 & 0.13 & 6.02 & 8.85 & 4.18 & 2.19 & 0.57 & 64 & 134 & 1650 & 947 & 20.5 & 218 & N.C. & N.C. \\
\hline
\end{tabular}

T, J and W' 88 -eruptive temperature (in ${ }^{\circ} \mathrm{C}$ ) calculated via the method of Jurewicz and Watson (1988); see lext for discussion.

T, S '00-enuptive temperature (in " ${ }^{\circ}$ ) calculated via the method of Sugawara (2000); see text for discussion.

N.C.-not calculated, due to apparent olivine-liquid disequilibria.

See lext for explenation.

IH-Indian Heaven; MA-Mount Adams; MSH-Mount St. Helens; FA-frontal arc.

c of-olivine (with spinel inclusions); pl-plagioclase; cpx-clinopyroxene; amph-amphibole; tr.-trace; mp.-microphenocrystic. 
Table 2:

Table 2

Representative and yses of olivine and spinel puis in SWC basalts

\begin{tabular}{|c|c|c|c|c|c|c|c|c|c|c|c|c|c|c|c|c|}
\hline \multirow[t]{2}{*}{ Sample no. } & \multirow{2}{*}{\multicolumn{2}{|c|}{$\begin{array}{l}\text { Magma } \\
\text { type }\end{array}$}} & \multirow{2}{*}{\multicolumn{2}{|c|}{$\begin{array}{l}\text { Ganeral } \\
\text { locition* }\end{array}$}} & \multicolumn{12}{|c|}{ Olivine compositions } \\
\hline & & & & & \multirow{2}{*}{$\frac{\mathrm{SiO}_{2}}{39.09}$} & \multicolumn{2}{|c|}{$\mathrm{Cr}_{2} \mathrm{O}_{3}$} & \multirow{2}{*}{$\frac{\mathrm{FeO}}{13.69}$} & \multicolumn{2}{|c|}{$\mathrm{Mmo}$} & \multirow{2}{*}{$\frac{\mathrm{NiO}}{0.22}$} & \multirow{2}{*}{$\frac{\mathrm{MgO}}{44.69}$} & \multirow{2}{*}{$\frac{\mathrm{CaO}}{0.20}$} & \multicolumn{2}{|c|}{ Sum } & \multirow{2}{*}{$\frac{\text { Fo }}{853}$} \\
\hline LOO-1 4 & & KT & IH & & & 0.08 & & & 0.24 & & & & & & 8.21 & \\
\hline DS-6A- $=0$ & & KT & IH & & 39.91 & 0.06 & & 15.15 & 0.26 & & 0.27 & 45.33 & 0.17 & & 1.17 & 84.2 \\
\hline DS- $90 A-\$ 0$ & & KT & IH & & 39.54 & 0.06 & & 16.71 & 0.18 & & 0.27 & 4337 & 0.20 & & 0.44 & 82.2 \\
\hline DS-41-81 & & KT & IH & & 39.66 & 0.04 & & 17.12 & 0.24 & & 0.17 & 43.49 & 0.19 & & 0.93 & 81.9 \\
\hline$L 00-24$ & & KT & MA & & 39.04 & 0.11 & & 15.58 & 0.18 & & 0.27 & 43.71 & 0.26 & & 9.15 & 833 \\
\hline DS-78-MSH & & $\mathrm{IB}$ & MSH & & 39.73 & 0.18 & & 15.04 & 0.17 & & 0.17 & 44.75 & 0.10 & & 0.19 & 84.1 \\
\hline DS-4-MSH & & IIB & MSH & & 39.78 & 0.20 & & 16.11 & 0.22 & & 0.19 & 43.61 & 0.20 & & 0.31 & 82.8 \\
\hline DS-69A- $\$ 0$ & & IIB & IH & & 37.73 & 0.00 & & 25.47 & 0.39 & & 0.14 & 35.66 & 0.11 & & 9.93 & 71.4 \\
\hline DS-46-80 & & IB & IH & & 39.24 & 0.07 & & 14.87 & 0.48 & & 0.13 & 44.68 & 0.15 & & 9.64 & 843 \\
\hline DS-2A 200 & & IB & IH & & 39.83 & 0.02 & & 1733 & 0.22 & & 0.21 & 43.47 & 0.17 & & 1.25 & 81.7 \\
\hline DS $-20-90$ & & IB & IH & & 39.57 & 0.05 & & 16.15 & 0.21 & & 0.26 & 43.09 & 0.32 & & 9.69 & 82.6 \\
\hline DS-26A $=00$ & & IIB & IH & & 39.78 & 0.17 & & 15.03 & 0.21 & & 0.22 & 45.28 & 0.19 & & 0.88 & 843 \\
\hline LO124 & & IB & MA & & 40.01 & 0.06 & & 12.36 & 0.20 & & 0.34 & 46.37 & 0.16 & & 9.50 & 87.0 \\
\hline Lolies & & IIB & MA & & 39.30 & 0.01 & & 14.28 & 0.20 & & 0.23 & 44.54 & 0.20 & & 8.75 & 84.8 \\
\hline LO0:8 & & LLK & FA & & 39.30 & 0.20 & & 14.48 & 0.21 & & 0.22 & 44.94 & 0.19 & & 9.60 & 84.7 \\
\hline LO1-17 & & ALK & MSH & & 39.34 & 0.00 & & 15.84 & 0.26 & & 0.21 & 4339 & 0.24 & & 28 & 83.0 \\
\hline DS-7-MSH & & ULK & MSH & & 38.33 & 0.15 & & 15.11 & 0.21 & & 0.23 & 43.88 & 0.04 & & 8.01 & 83.8 \\
\hline DS-9MSH & & LLK & MSH & & 39.01 & 0.19 & & 1533 & 0.21 & & 0.22 & 45.21 & 0.02 & & 0.26 & 84.0 \\
\hline LO1.3b & & $\hat{A}$ & FA & & 39.63 & 0.08 & & 1234 & 0.14 & & 0.27 & 46.04 & 0.15 & & 8.64 & 86.9 \\
\hline L006 6 & & $\hat{A}$ & FA & & 39.43 & 0.24 & & 16.16 & 0.33 & & 0.11 & 43.23 & 0.28 & & 9.83 & 82.7 \\
\hline LO16 & & A & FA & & 39.95 & 0.18 & & 1130 & 0.20 & & 0.34 & 47.60 & 0.13 & & 9.70 & 883 \\
\hline L0121 & & A & MA & & 40.07 & 0.08 & & 12.21 & 0.19 & & 0.41 & 46.88 & 0.16 & & 0.00 & 873 \\
\hline L0123 & & $\mathbf{A}$ & MA & & 40.25 & 0.02 & & 11.63 & 0.12 & & 0.48 & 46.98 & 0.14 & & 9.62 & 87.8 \\
\hline LOO-10 & & $\hat{\Lambda}$ & FA & & 40.66 & 0.48 & & 13.44 & 0.16 & & 0.12 & 45.74 & 0.08 & & 0.68 & 85.9 \\
\hline LO1S & & $\mathbf{A}$ & FA & & 38.94 & 0.21 & & 16.78 & 0.21 & & 0.23 & 42.76 & 0.10 & & 9.23 & 82.0 \\
\hline LO1-11 & & $\mathbf{B A}$ & FA & & 40.00 & 0.06 & & 10.56 & 0.17 & & 0.40 & 47.71 & 0.12 & & 9.02 & 89.0 \\
\hline DS-42-81 & & HOS & IH & & 38.86 & 1.86 & & 12.47 & 0.15 & & 0.37 & 46.90 & 0.07 & & 1135 & 87.0 \\
\hline \multirow[t]{3}{*}{ DS-23B-81 } & & HOS & IH & & 40.18 & 0.03 & & 13.73 & 0.28 & & 0.27 & 46.26 & 0.16 & & 0.91 & 85.7 \\
\hline & \multicolumn{16}{|c|}{ Spind compositions } \\
\hline & $\overline{\mathrm{SiO}_{2}}$ & $\mathrm{TiO}_{2}$ & $\mathrm{~N}_{2} \mathrm{O}_{3}$ & $\mathrm{~V}_{2} \mathrm{O}_{3}$ & $\mathrm{C}_{2} \mathrm{O}_{3}$ & $\mathrm{Fe}_{2} \mathrm{O}_{3}$ & $\mathrm{FeO}$ & $\mathrm{MnO}$ & $\mathrm{MgO}$ & No & $\mathrm{ZnO}$ & SUM** & $\mathrm{Fe}^{2+} / \mathrm{Fe}^{3+}$ & MoH & $\mathrm{OH}$ & $\mathrm{Fe}^{3+}=$ \\
\hline LOO-1 4 & 0.17 & 0.40 & 39.65 & $\mathrm{n} . \mathrm{a}$ & 21.56 & 7.44 & 13.74 & 0.13 & 15.98 & 0.19 & 0.07 & 9933 & 2.05 & 67.5 & 26.7 & 8.1 \\
\hline DS-6A- -90 & nd. & 0.46 & 40.90 & 0.18 & 22.13 & 6.82 & 14.52 & 0.15 & 15.84 & 0.25 & 0.07 & 101.23 & 2.37 & 66.0 & 26.7 & 7.2 \\
\hline DS- $80 A-20$ & nd. & 0.38 & 46.34 & 0.12 & 16.98 & 5.81 & 15.97 & 0.13 & 15.53 & 0.16 & 0.13 & 10156 & 3.05 & 63.4 & 19.7 & 6.0 \\
\hline DS-41-81 & nd. & 0.47 & 40.09 & 0.17 & 18.19 & 10.63 & 15.87 & 0.21 & 14.79 & 0.11 & 0.02 & 100.54 & 1.66 & 62.4 & 23.3 & 11.5 \\
\hline L00-24 & 0.24 & 0.61 & 42.86 & $\mathrm{n} . \mathrm{n}$ & 18.12 & 6.88 & 15.42 & 0.12 & 15.54 & 0.21 & 0.10 & 100.09 & 2.49 & 64.2 & 22.1 & 7.4 \\
\hline DS-78-MSH & 0.10 & 0.99 & 31.33 & 0.28 & 26.68 & 8.71 & 17.02 & 0.33 & 13.01 & 0.24 & $\mathrm{n} n$ & 98.69 & 2.17 & 57.7 & 36.3 & 10.1 \\
\hline DS-4MSH & 0.25 & 1.17 & 32.91 & 0.23 & 22.91 & 9.78 & 18.63 & 0.37 & 1235 & 0.22 & $\mathrm{n} . \mathrm{n}$ & 98.62 & 2.120 & 54.2 & 31.8 & 11.5 \\
\hline DS- $69 \mathrm{~A}=20$ & 0.00 & 16.78 & 237 & 0.61 & 2.79 & 30.65 & 42.15 & 0.34 & 2.48 & 0.16 & 0.22 & 98.55 & 153 & 95 & 44.1 & 82.2 \\
\hline DS-46-90 & 0.00 & 0.4 & 6.51 & 0.17 & 10.57 & 5281 & 23.91 & 0.44 & 5.42 & 0.10 & 0.04 & 10035 & 0.50 & 29.0 & 52.6 & 71.2 \\
\hline DS-2A-90 & nd. & 1.50 & 27.28 & 0.22 & 27.87 & 11.03 & 21.90 & 0.24 & 9.94 & 0.14 & 0.21 & 100.76 & 2.21 & 44.7 & 40.7 & 133 \\
\hline DS-20-90 & 0.39 & 1.54 & 36.96 & 0.27 & & 8.15 & & nd. & 13.98 & 0.16 & $\mathrm{n} . \mathrm{A}$ & 97.19 & 2.37 & 58.9 & 25.7 & 95 \\
\hline DS-26A $\$ 0$ & nd. & 0.90 & 33.75 & 0.17 & 25.88 & 9.40 & 16.73 & 0.26 & 13.66 & 0.34 & 0.09 & 101.08 & 1.98 & 593 & 34.0 & 10.5 \\
\hline LO124 & 0.18 & 0.56 & 4130 & $\mathrm{n} . \mathrm{n}$ & 18.90 & 9.72 & 12.60 & 0.16 & 17.17 & 0.37 & 0.13 & 101.07 & 1.44 & 70.8 & 23.5 & 10.3 \\
\hline Lo12s & 0.12 & 0.51 & 4208 & $\mathrm{n} n$ & 16.75 & 10.21 & 14.83 & 0.21 & 15.66 & 0.17 & 0.27 & 100.81 & 1.61 & 653 & 21.1 & 10.9 \\
\hline LO0:8 & 0.37 & 1.46 & 2931 & 0.25 & 25.48 & 10.56 & 17.17 & nd. & 13.23 & 0.24 & $\mathrm{n} . \mathrm{s}$ & 98.08 & 1.81 & 57.8 & 36.8 & 12.7 \\
\hline LO1-17 & 0.15 & 1.00 & 38.85 & $\mathrm{n} . \mathrm{a}$ & 1932 & 10.52 & 16.38 & 0.12 & 14.90 & 0.25 & 0.11 & 101.60 & 1.73 & 61.9 & 25.0 & $11 \mathrm{~s}$ \\
\hline DS-7MSH & 0.27 & 1.01 & 40.53 & 0.19 & 16.56 & 6.59 & 16.48 & 0.27 & 14.00 & 0.21 & $\mathrm{n} . \mathrm{A}$ & 95.44 & 2.78 & 60.2 & 21.5 & 75 \\
\hline DS-9MSH & 0.06 & 1.14 & 40.78 & 0.20 & 17.72 & 7.25 & 16.16 & 0.14 & 14.68 & 0.22 & $\mathrm{n} n$ & 97.62 & 2.48 & 61.8 & 22.6 & 8.1 \\
\hline LO1/3b & 0.09 & 0.95 & 19.69 & $\mathrm{n} n$ & 35.34 & 13.69 & 18.77 & 0.21 & 10.90 & 0.27 & 0.19 & 100.00 & 1.52 & 50.6 & 54.6 & 16.8 \\
\hline
\end{tabular}


Table 2 (continued)

\begin{tabular}{|c|c|c|c|c|c|c|c|c|c|c|c|c|c|c|c|c|}
\hline & \multicolumn{16}{|c|}{ Spinel compositions } \\
\hline & $\overline{\mathrm{SiO}_{2}}$ & $\mathrm{TiO}_{2}$ & $\mathrm{Al}_{2} \mathrm{O}_{3}$ & $\mathrm{~V}_{2} \mathrm{O}_{3}$ & $\mathrm{Cr}_{2} \mathrm{O}_{3}$ & $\mathrm{Fe}_{2} \mathrm{O}_{3}$ & $\mathrm{FeO}$ & $\mathrm{MnO}$ & $\mathrm{MgO}$ & $\mathrm{NiO}$ & $\mathrm{ZnO}$ & SUM* & $\mathrm{Fe}^{2+} / \mathrm{Fe}^{3+}$ & $\mathrm{Mg} \#$ & $\mathrm{C} \#$ & $\mathrm{Fe}^{3+} \#$ \\
\hline L00-6 & 0.32 & 0.71 & 8.41 & 0.14 & 27.77 & 29.47 & 23.67 & n.d. & 5.96 & 0.11 & n.a. & 96.57 & 0.89 & 31.0 & 68.9 & 41.0 \\
\hline LO1-6 & 0.15 & 0.53 & 25.55 & n.a. & 34.89 & 11.10 & 13.58 & 0.26 & 14.91 & 0.28 & 0.13 & 101.37 & 1.36 & 66.2 & 47.8 & 12.6 \\
\hline L01-21 & 0.11 & 0.88 & 26.42 & n.a. & 32.32 & 11.19 & 14.55 & 0.22 & 14.37 & 0.39 & 0.03 & 100.48 & 1.45 & 63.7 & 45,1 & 12.9 \\
\hline L01-23 & 0.14 & 0.96 & 24.66 & n.a. & 32.67 & 12.36 & 14.52 & 0.18 & 14.15 & 0.31 & 0.23 & 100.18 & 1.30 & 63.5 & 47.1 & 14.5 \\
\hline LO0-10 & 0.05 & 1.20 & 20.32 & 0.22 & 33.14 & 11.65 & 18.43 & 0,42 & 10.30 & 0.43 & n.a. & 96.16 & 1.62 & 49.5 & 52.2 & 16.4 \\
\hline LO1-5 & 0.12 & 0.65 & 15.05 & n.a. & 38.76 & 14.38 & 21.76 & 0.14 & 8.14 & 0.19 & 0.31 & 99.50 & 1.68 & 40.0 & 63.3 & 18.3 \\
\hline LO1-11 & 0.14 & 0.47 & 25.13 & n.a. & 36.66 & 8.79 & 13.70 & 0.19 & 14.57 & 0.21 & 0.10 & 99.97 & 1.73 & 65.5 & 49.5 & 10.1 \\
\hline DS- $42-81$ & n.d. & 1.47 & 16.61 & 0.09 & 33.34 & 16.47 & 19.38 & 0.34 & 9.73 & 0.32 & 0.22 & 97.97 & 1.31 & 47.2 & 57,4 & 21.3 \\
\hline DS-23B-81 & n.d. & 0.19 & 15.35 & 0.17 & 22.75 & 32.90 & 19.10 & 0.28 & 9.42 & 0.59 & 0.07 & 100.81 & 0.65 & 46.8 & 49.8 & 40.7 \\
\hline
\end{tabular}

For each sample, compositions of adjacent spinel and olivine pairs are given.

n.d. =not detected; n.a. $=$ not analyzed; $\mathrm{Mg} \# 100 \mathrm{Mg} /\left(\mathrm{Mg}+\mathrm{Fe} e^{2+}\right) ; \mathrm{Cr} \#=100 \mathrm{Cr} /(\mathrm{Cr}+\mathrm{Al}) ; \mathrm{Fe}^{3+} \#=100 \mathrm{Fe}^{3+}\left(\mathrm{Fe}^{3+}+\mathrm{Cr}+\mathrm{Al}\right)$.

- Four samples have totals $<97.5 \mathrm{wt} \%$; however, only one (L00-10) is shown in Figs. 7-10 because the other three failed the olivine-melt equilibrium test (see Section 5.1).

Figure 2:

A
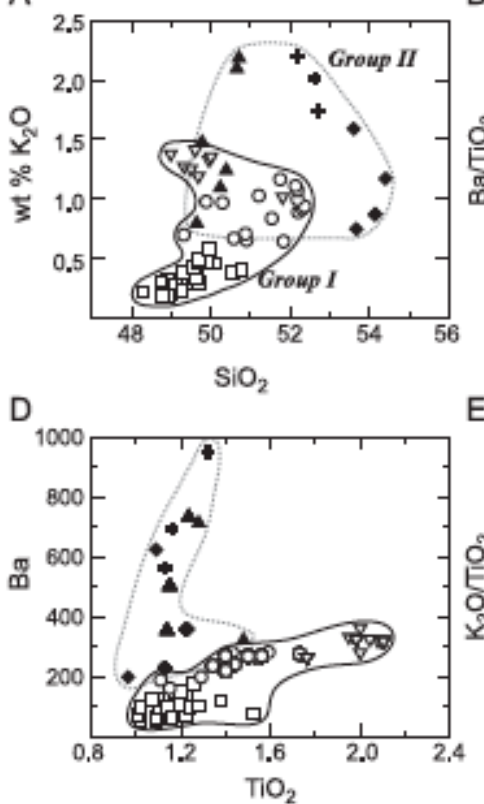

B

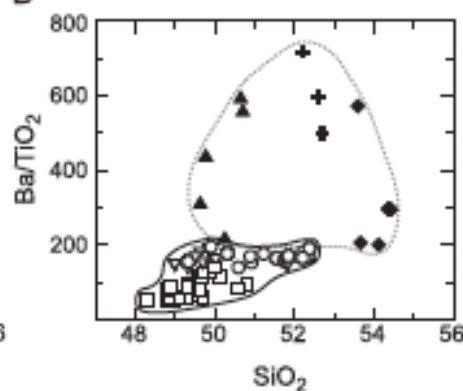

$\mathrm{E}$

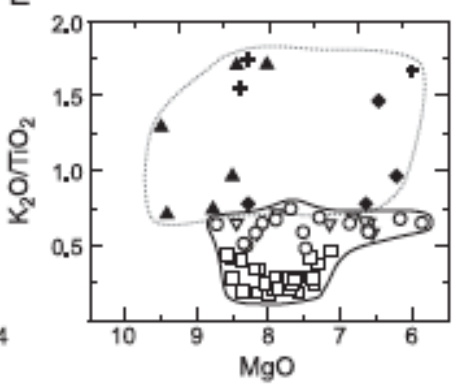

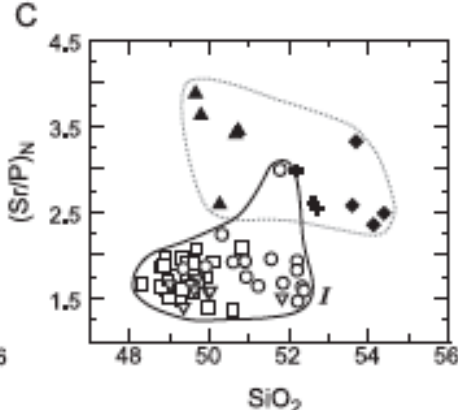

$\mathrm{F}$

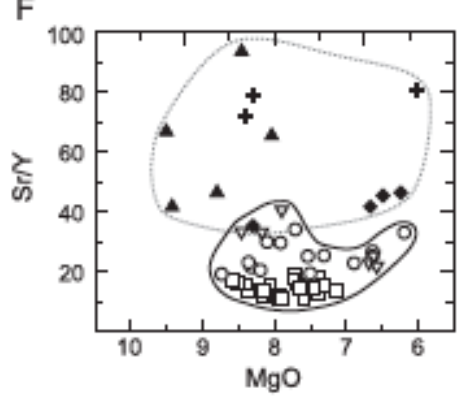

Fig. 2. Selected geochemical features of SWC basalts: (A) wt.\% $\mathrm{K}_{2} \mathrm{O}$ vs, wt.\% $\mathrm{SiO}_{2} ;(\mathrm{B}) \mathrm{Ba} / \mathrm{TiO}_{2}$ vs. wt.\% $\mathrm{SiO}$ normalized to Sun and McDonough's (1989) values of 21.2 and $95 \mathrm{ppm}$, respoctively) vs. wt.\% $\mathrm{SiO}_{2} ;(\mathrm{D}) \mathrm{Ba}$ (ppm) vs. wt.\% TiO $;$; (E) $\mathrm{K}_{2} \mathrm{O} /$ $\mathrm{TiO}_{2}$ vs. wt.\% MgO; (F) Sr/Y vs, wt.\% MgO. Group I lavas, open symbols inverted triangles=ALK; circles=OIB; squares=LKT. Group II lavas, filled symbols triangles=CA; diamonds=BA; crosses-SHOS. Full and dashed lines encircle Group I and II lavas, respectively. In addition to compositions given in Table 1, analyses of primitive lavas from Indian Heaven are also shown (Smith and Loeman, manuscript in preparation). See text for further discussion. 
Figure 3:

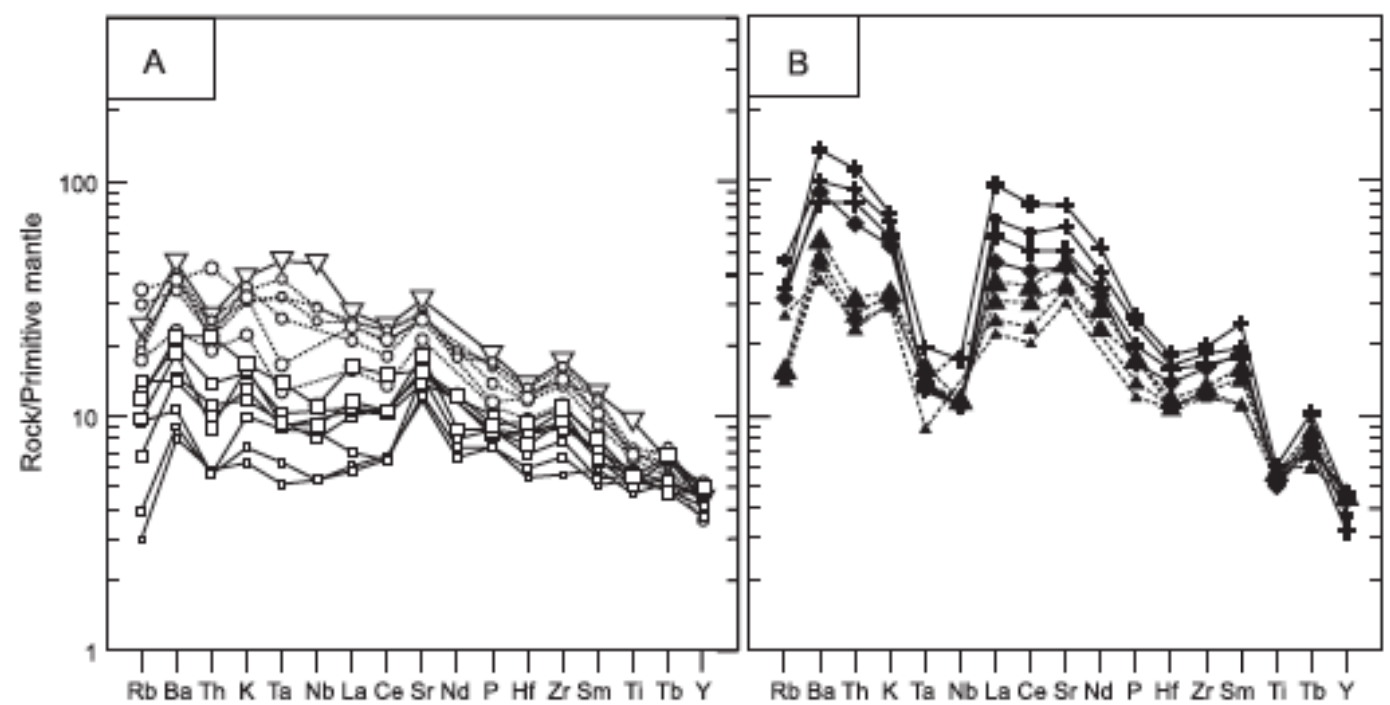

Fig. 3. Primitive mantle-normalized trace element pattems for (A) Group I and (B) Group II basalts (Leeman et al., 2004; Smith and Leeman, manuscript in preparation). Normalizing values from Sun and McDonough (1989); symbols as in Fig. 2.

Figure 4:

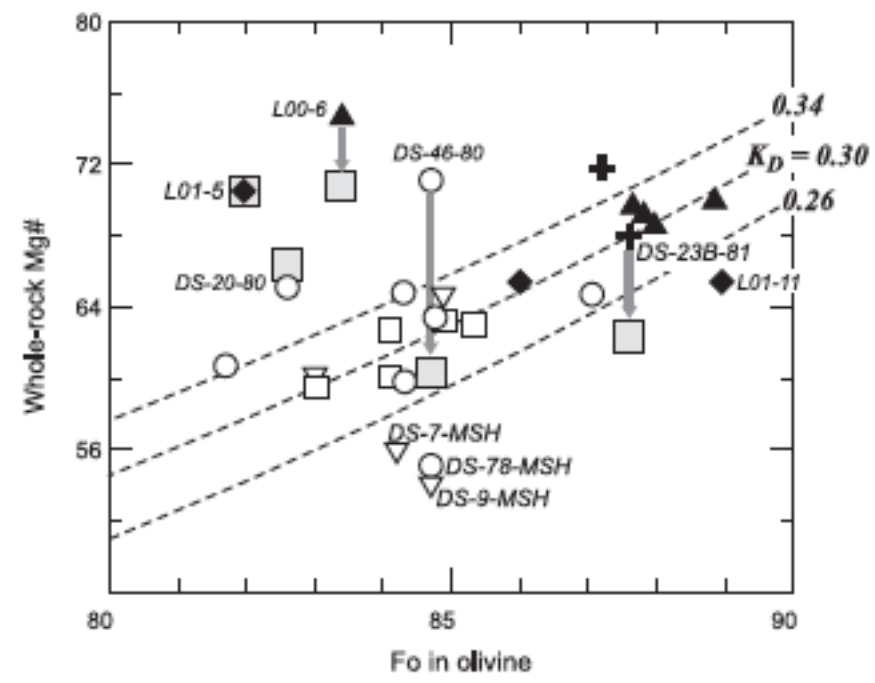

Fig. 4. Whole-rock $\mathrm{Mg} \#\left[=100 \mathrm{Mg} /\left(\mathrm{Mg}+\mathrm{Fe}^{2+}\right)\right]$ vs. forsterite (Fo) in olivine core compositions (error bars are indicated). With the exception of sample DS-69A-80 (which plots off scale), the maximum Fo content is plotted for each sample. Symbols as in Fig. 2, Dashed lines show olivine-liquid $K_{\mathrm{D}}$ contours. Shaded squares next to five data points represent shift in whole-rock $\mathrm{Mg}$ \# that occur as a result of using $\mathrm{Fe}^{3+}+$ $\Sigma \mathrm{Fe}=0.15$ instead of higher values suggested by chemistry of spinels in those samples (soe text for further explanation). 
Figure 5:
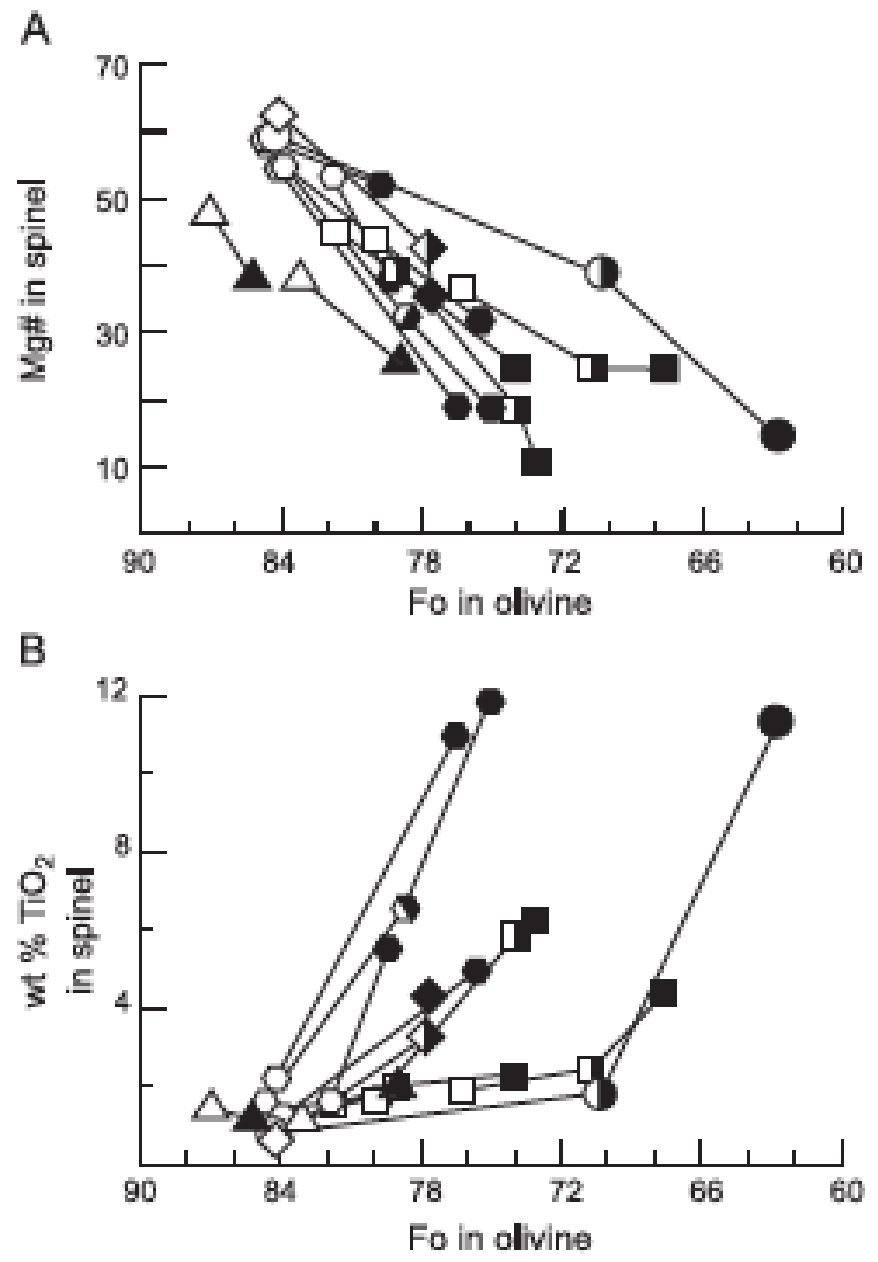

Fig. 5. Compositional trends in (A) Mg\# in spinel and (B) wt.\% $\mathrm{TiO}_{2}$ in spinel vs. Fo in olivine for contiguous olivine-spinel pairs analyzed within individual olivine phenocrysts. Tie-lines connect olivine-spinel pairs occurring in cores (open symbols) with pairs in rims (filled symbols) for 11 phenocryst occurring in five different samples DS-6A-80 (LKT), diamonds; DS-2A-80 (OIB), squares; DS-26A-80 (OIB), circles; L00-8 (ALK), hexagons; DS-42-81 (SHOS), triangles. Half-filled symbols represent points between cores and rims. 
Figure 6:
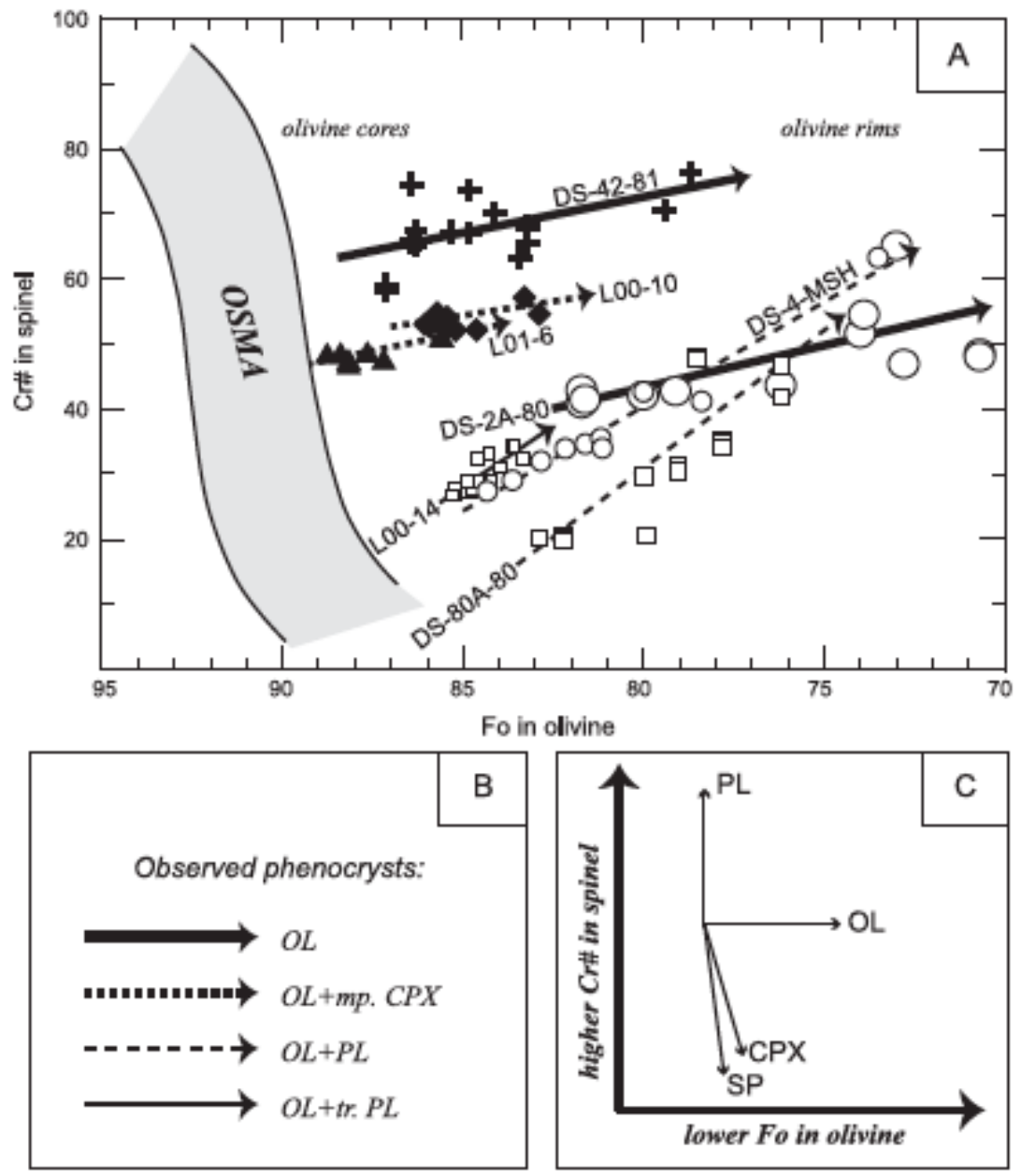

Fig. 6. (A) $\mathrm{Cr} \#[=100 \mathrm{Cr} /(\mathrm{Cr}+\mathrm{AD})]$ in spinel vs. Fo in olivine for seven selected $\mathrm{SWC}$ samples Symbols as in Fig. 2, OSMA=olivine-spinel mantle array (from Arai, 1994). For each sample, best-fit lines are drawn through all available olivine-spinel pairs. (B) Best-fit lines drawn in (A) are keyed to phenocrys phases observed in each sample (mp.=microphenocrystic; tr.=trace). (C) Fractionation vectors for plagioclase (PL), olivine (OL), clinopyroxene (CPX), and spinel (SP). See text for discussion. 
Figure 7:
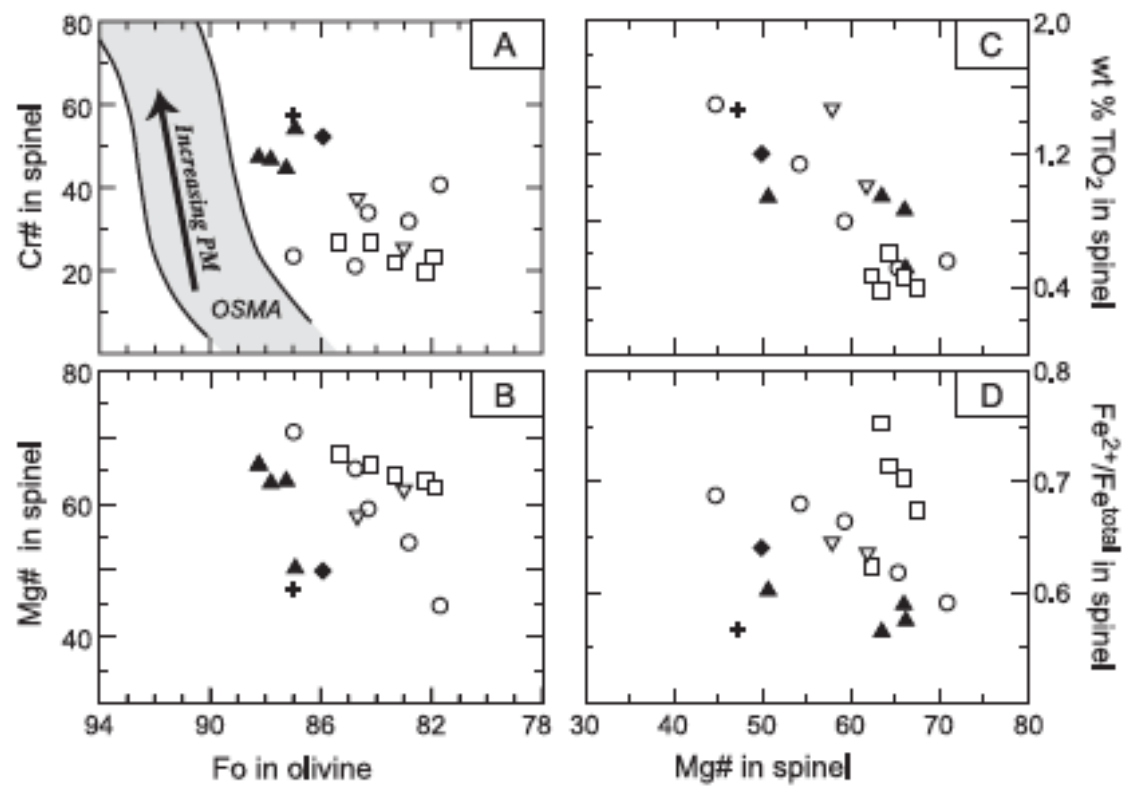

Fig. 7. (A) $\mathrm{Cr}$ in spinel and (B) $\mathrm{Mg} \#$ in spinel vs. Fo in olivine; (C) wt.\% $\mathrm{TiO}_{2}$ in spinel and (D) $\mathrm{Fe}^{2+} / \Sigma \mathrm{Fe}$ in spinel vs. Mg\# in spinel. Symbols as in Fig. 2. Only those analyses that meet criteria for most primitive spinels are shown (see text for discussion). Panel (A) illustrates the olivine-spinel mantle array (OSMA; from Arai, 1994). A vector plotted within the OSMA array illustrates the trend in Cr\# in spinel and Fo in olivine with increasing degree of partial melting (or decreasing source fertility). Note that for an anhydrous fertile peridotite source, $30 \%$ partial melting is required to increase Cr\# from 15 to 60 (Baker and Stolper, 1994; Clynne and Borg, 1997). 
Figure 8:
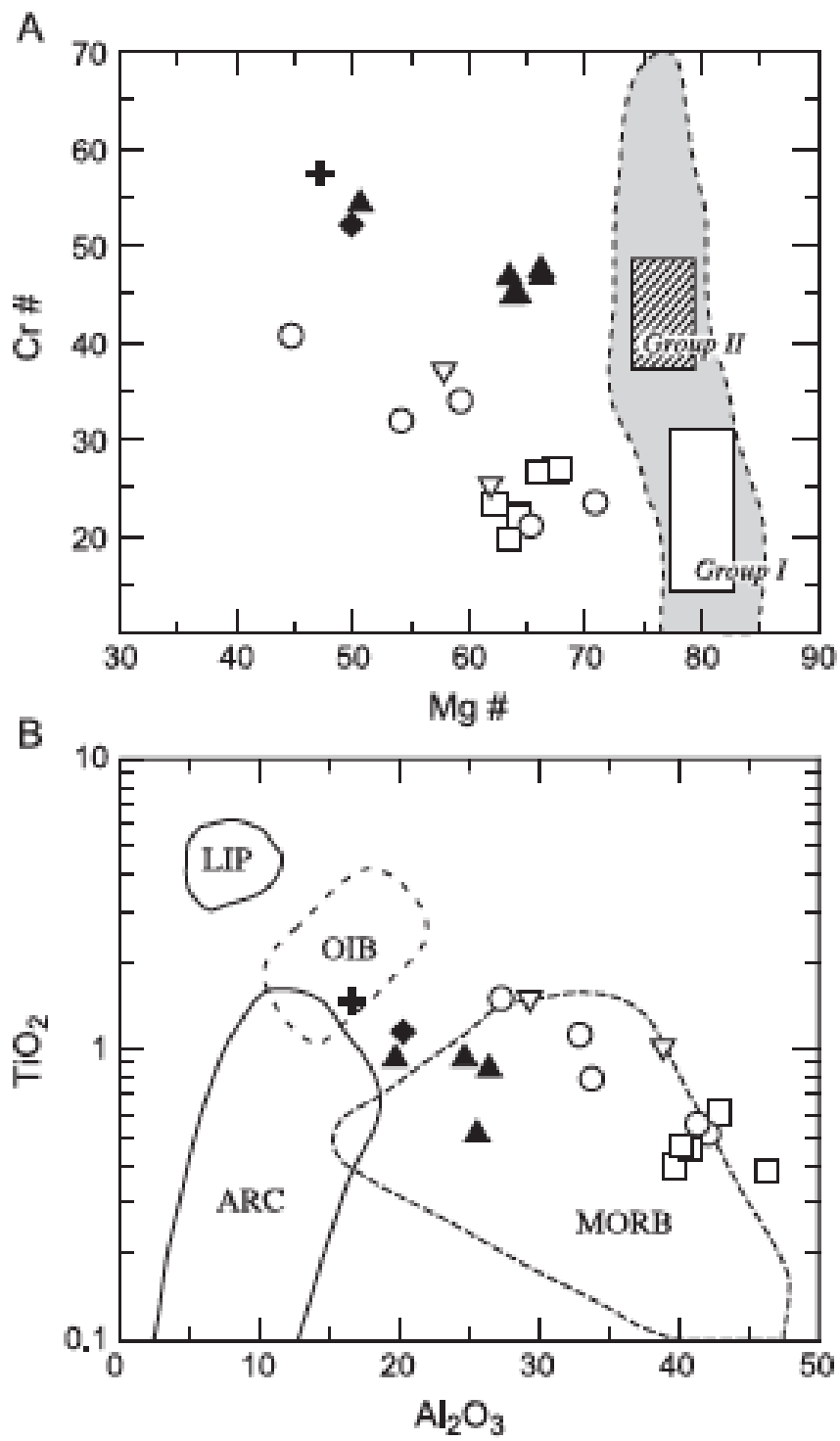

Fig. 8. Additional chemical features of spinels in SWC basalts (only those analyses that meet the criteria for most primitive compositions are shown). Symbols as in Fig. 2. (A) Cr\# vs, Mg\#. The dashed outlined field includes compositions of spinels during progressive melting of mantle peridotite (from Baker and Stolper, 1994; Wasylenki et al., 2003; Matsukage and Kubo, 2003). Estimates of primary spinel compositions for Group I and II are shown by open and ruled rectangles, respectively. These estimates were made by assuming that liquidus spinels are compositionally similar to those in the source residuum and by taking into account changes in $\mathrm{Cr} \#$ and $\mathrm{Mg} \#$ expected during magma evolution (cf. Section 5.2). (B) Wt.\% $\mathrm{Al}_{2} \mathrm{O}_{3}$ vs. wt.\% $\mathrm{TiO}_{2}$. Fields are shown for spinels from large igneous provinces (LIP), ocean island basalts (OIB), arc basalts (ARC) and mid-ocean ridge basalts (MORB) (after Kamenetsky et al., 2001). 
Figure 9:

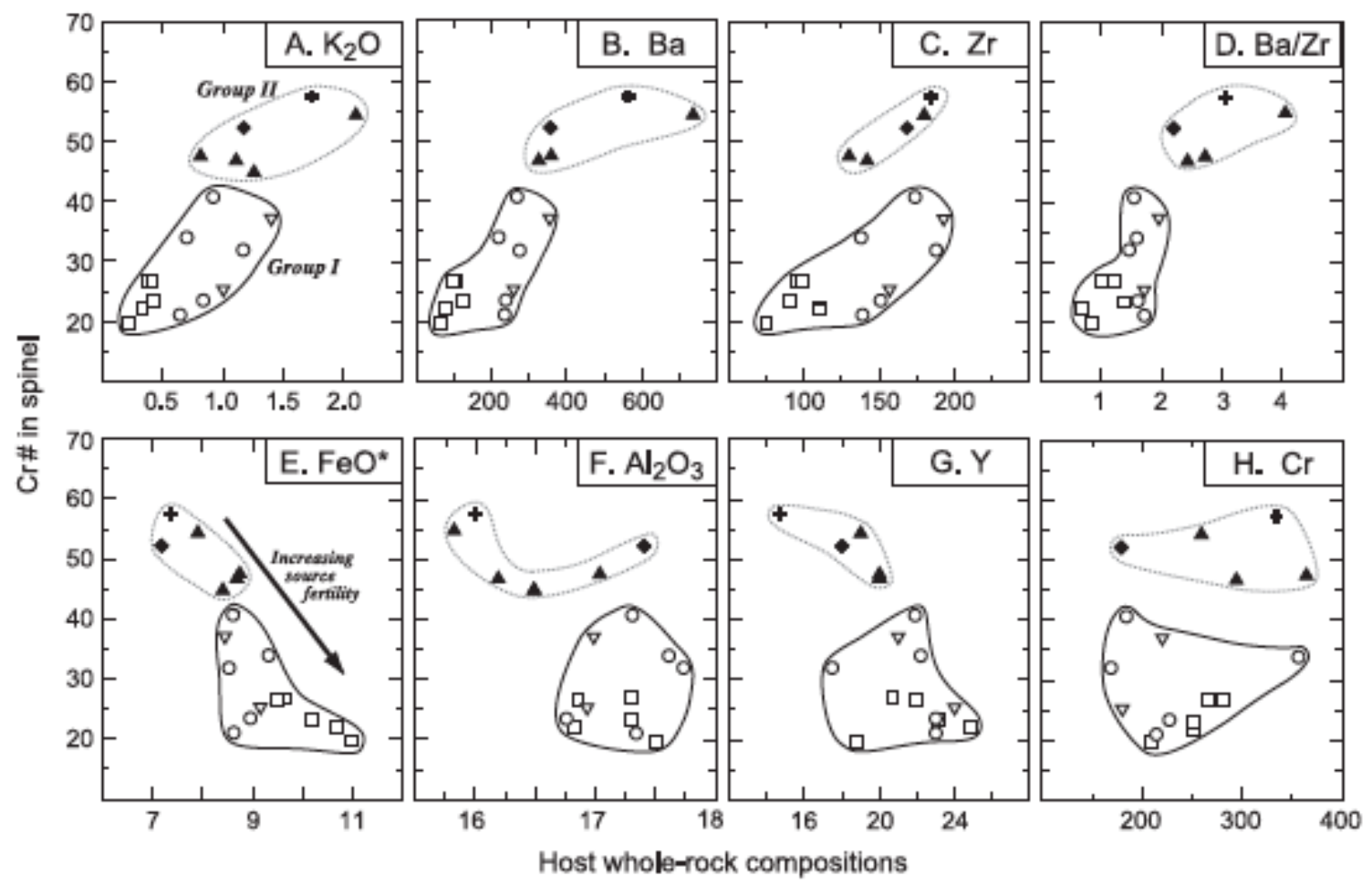

Fig. 9. $\mathrm{C} \#$ in spinel vs. (A) wt.\% $\mathrm{K}_{2} \mathrm{O}$, (B) $\mathrm{Ba}$ (ppm), (C) Zr (ppm) (D) $\mathrm{Ba} / \mathrm{Zr}$, (E) wt.\% FeO*, (F) wt \% $\mathrm{Al}_{2} \mathrm{O}_{3},(\mathrm{G}) \mathrm{Y}$ (ppm), and $(\mathrm{H}) \mathrm{Cr}(\mathrm{ppm})$ in the host rock. Symbols and lines as in Fig. 2. Only those spinels that meet criteria for most primitive compositions are shown. 
Figure 10:
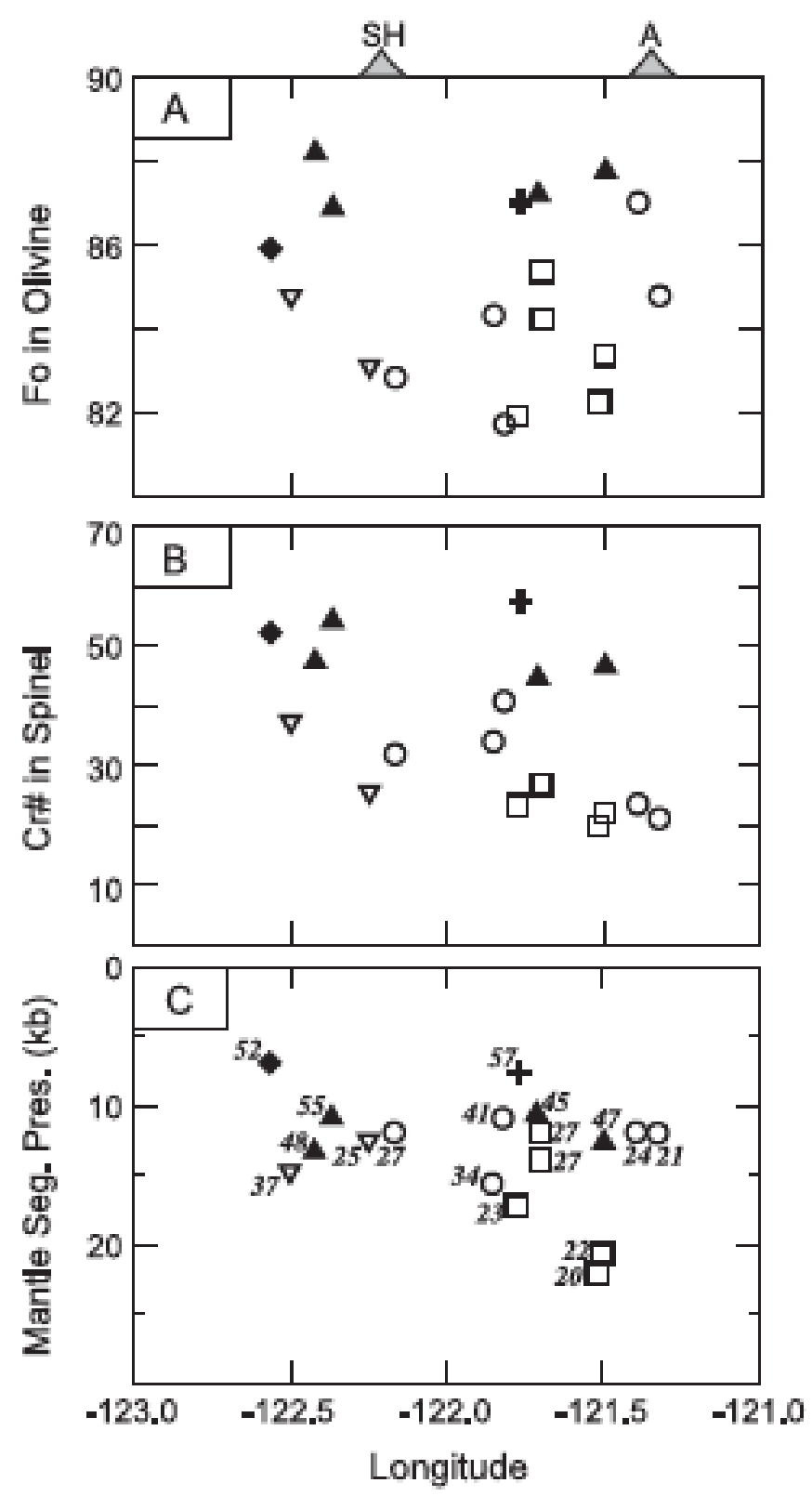

Fig. 10. (A) Fo in olivine, (B) $\mathrm{Cr} \#$ in spinel, and (3) mantle segregation pressure (in kilobars) vs. sample location given by longitude (cf. Table 1). Pressures are from Leeman et al. (2005, Table 1) and were calculated via the method of Albaride (1992). Numbers adjacent to data points in panel (C) represent the spinel $\mathrm{Cr}$ \# (also illustrated in panel (B)). Only the most primitive olivine and spinel compositions are illustrated. Symbols as in Fig. 2; SH=Mount St. Helens; A=Mount Adams. 